\title{
Transition Metal Phosphides for the Catalytic Hydrodeoxygenation of Waste Oils into Green Diesel
}

\author{
M. Consuelo Alvarez-Galvan * (D), Jose M. Campos-Martin * (i) and Jose L. G. Fierro * \\ Energy and Sustainable Chemistry Group (EQS), Instituto de Catálisis y Petroleoquímica, CSIC, c/Marie Curie, \\ 2 Cantoblanco, 28049 Madrid, Spain \\ * Correspondence: c.alvarez@icp.csic.es (M.C.A.-G.); jm.campos@csic.es (J.M.C.-M.); \\ jlgfierro@icp.csic.es (J.L.G.F.)
}

Received: 28 February 2019; Accepted: 15 March 2019; Published: 22 March 2019

\begin{abstract}
Recently, catalysts based on transition metal phosphides (TMPs) have attracted increasing interest for their use in hydrodeoxygenation (HDO) processes destined to synthesize biofuels (green or renewable diesel) from waste vegetable oils and fats (known as hydrotreated vegetable oils (HVO)), or from bio-oils. This fossil-free diesel product is produced completely from renewable raw materials with exceptional quality. These efficient HDO catalysts present electronic properties similar to noble metals, are cost-efficient, and are more stable and resistant to the presence of water than other classical catalytic formulations used for hydrotreatment reactions based on transition metal sulfides, but they do not require the continuous supply of a sulfide source. TMPs develop a bifunctional character (metallic and acidic) and present tunable catalytic properties related to the metal type, phosphorous-metal ratio, support nature, texture properties, and so on. Here, the recent progress in TMP-based catalysts for HDO of waste oils is reviewed. First, the use of TMPs in catalysis is addressed; then, the general aspects of green diesel (from bio-oils or from waste vegetable oils and fats) production by HDO of nonedible oil compounds are presented; and, finally, we attempt to describe the main advances in the development of catalysts based on TMPs for HDO, with an emphasis on the influence of the nature of active phases and effects of phosphorous, promoters, and preparation methods on reactivity.
\end{abstract}

Keywords: transition metal phosphides (TMPs); hydrodeoxygenation (HDO); hydrotreated vegetable oils (HVO)

\section{Introduction}

The production of chemicals and fuels using waste biomass as the raw material has attracted scientific and industrial interest because these processes produce zero carbon dioxide emissions, which helps to solve global warming. With this aim, the European Union has established a target of obtaining $32 \%$ of energy from renewable sources by 2030 , and the use of fuels produced from biomass could help to achieve this goal by replacing the use of petroleum-based fuels [1].

Processes that produce biodiesel from biomass or plant oils are an alternative to petroleum-based fuels. Traditional biodiesel is obtained by transesterification, converting triglycerides to methyl esters [2]. A very interesting alternative to the esterification process is the hydrotreatment of vegetable oils or animal fats, the fuel obtained after this hydrotreatment is known as renewable diesel. Hydrotreatment of vegetable oils or animal fats is one of the more attractive processes in the production of biofuels in terms of carbon mass balance (approximately 95\%) [3]. The quality of the hydrotreated vegetable oils (HVOs) is clearly higher than that of ester-type biodiesel fuels. HVOs do not produce increases in NOx emission, the formation of deposits is minimized, they have a long stability, they have a high compatibility with engine oil, and they have good cold properties. HVOs 
are straight chain paraffinic hydrocarbons without aromatics, oxygen, and sulfur, and with high cetane numbers [4]. These properties endow HVO fuels with an extraordinary quality that surpasses biodiesel (fatty acid methyl esters, FAME) and crude oil diesel [3]. The use of hydrotreated vegetable oil (HVO) enables reductions in $\mathrm{CO}$, total hydrocarbon, and NOx emissions, as well as engine smoke, compared with crude oil-based diesel fuel, without any changes to the engine or its controls [4].

Another possible source of biofuels with diesel properties are those derived from lignocellulosic wastes, which have attracted great attention as they do not compete with the food industry. Among the different thermochemical treatments to convert biomass wastes in a resource such a liquid fuel, pyrolysis, gasification, and liquefaction, the first process-fast pyrolysis, in which the waste biomass is rapidly heated in the absence of oxygen producing bio-oil or pyrolysis oil—is the one that maximizes its production $[5,6]$. However, this product cannot be directly used because of its high content of oxygenates, in the form of phenols, furans, carboxylic acids, ethers, and aromatics alcohols. These oxygen groups cause poor properties for a liquid fuel such as low heating value and poor stability [7-9]. HDO, based on the catalytic removal of oxygen [10], is considered as an efficient and proper method for upgrading of bio-oil, producing renewable or green diesel.

Traditionally, transition metal sulfides have been used for hydrotreatment reactions; however, these compounds require a sulfide source and display poor stability in the presence of water. More recently, transition metal carbide, nitride, boride, and phosphide catalysts have increased in importance [11,12], in particular since the end of the 1990s, transition metal phosphides (TMPs) have been described as a family of high activity hydrotreatment catalysts. These materials are compounds between phosphorus and transition metals that combine physical properties, such as the hardness and strength that is typical of ceramics, with electronic properties, such as the conductivity that is characteristic of metals. Moreover, transition metal phosphides have some advantages, as HDO catalysts, compared with other active phases, such as noble metals and transition metal sulfides, among them are their cost-effectiveness and more environmentally-friendliness [13]. Previous studies with $\mathrm{Fe}_{2} \mathrm{P}$, CoP, and $\mathrm{Co}_{2} \mathrm{P}$ showed moderate activity, while the activity of silica-supported $\mathrm{Ni}_{2} \mathrm{P}$ was high, particularly in hydrogenation reactions [14,15]. Among the phosphides studied, MoP and WP [16] and the iron group have been reported to be more active than metal sulfides.

\section{Metal Phosphides and Catalysis}

Transition metal phosphides (TMP) are an interesting class of materials and are worth investigating at the nanoscale because of their wide scope of properties and applications. When used as catalytic materials, metal-rich phosphides show excellent activity in hydrogenation reactions. The nature, structure and synthesis of phosphides have been described in a number of reviews [17-22].

\subsection{Metal Phosphide Structures}

The compounds that contain phosphorus along with other elements of the periodic table are known as phosphides. The character of the bonds present in the phosphides depends on the nature of the counter-cation, being ionic in the case of alkali and alkaline earth metals, metallic or covalent for the transition elements, and clearly covalent for the main group elements. Transition metal phosphides (TMPs) have been suggested to be ideal catalysts owing to their low cost, abundance, and high efficiency [21,22]. In many areas, TMPs can be applied as stable and efficient catalytic materials. Depending on the composition of the metal phosphides, two main families have been distinguished: phosphorus-rich and metal-rich phosphides. A large number of TMPs have been described, namely, more than one hundred monometallic TMPs with compositions ranging from metal-rich $\mathrm{M}_{4} \mathrm{P}$ to phosphorus-rich $\mathrm{MP}_{15}$, and approximately one hundred bimetallic $(\mathrm{M})_{\mathrm{x}}\left(\mathrm{M}^{\prime}\right)_{\mathrm{y}} \mathrm{P}_{\mathrm{z}}$ metal phosphides [18,23]. From the perspective of catalysis, the most interesting compounds are the metal-rich phosphides, which possess metallic and ceramic properties, are good conductors of heat and electricity, and display high thermal and chemical stability [21]. 
In a first approach, because of the similar physical and chemical properties of TMPs, carbides, and nitrides, a similar crystal structure is expected. Nevertheless, the difference in the atomic radius among phosphorous and carbon or nitrogen implies a different structure because phosphorus does not fit in octahedral holes, like its counterparts $(\mathrm{C}$ or $\mathrm{N})$ do. For this reason, the crystalline structures of phosphides are based on metal atoms in the form of triangular prisms surrounded by phosphorus atoms, see Figure 1 ([21,24]. For metal-rich phosphides, the structures change to form a nine-fold tetrakaidecahedral (TKD) coordination with additional metal atoms placed near the centers of the vertical faces of the prism (Figure 1).
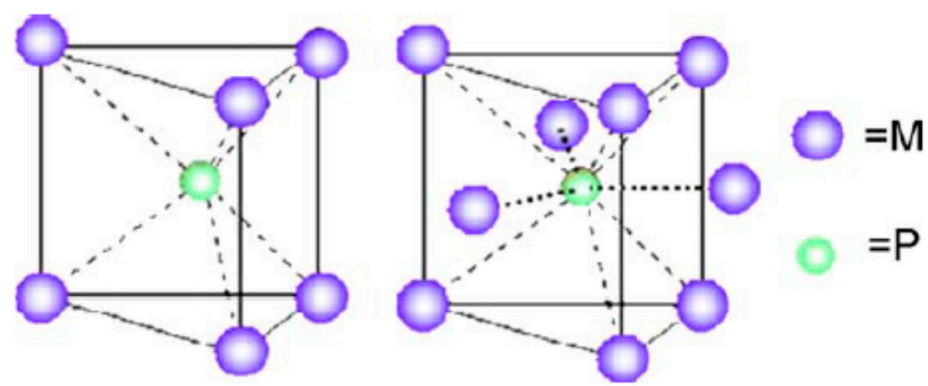

Figure 1. Triangular prism and tetrakaidecahedral structures of phosphides. (Reproduced from the work of [21] with permission).

Starting with these building blocks, several different arrangements produce several structures observed for TMPs. Figure 2 shows a summary of the five main families of TMPs [21]. Among the TMPs, the most common studied materials are based on $\mathrm{Co}, \mathrm{Ni}, \mathrm{Fe}$, and $\mathrm{Mo}$; however, some other TMPs have recently been studied, including $\mathrm{W}, \mathrm{Mn}, \mathrm{Cu}$, and so on.

Crystal Structures of Transition Metal Phosphides

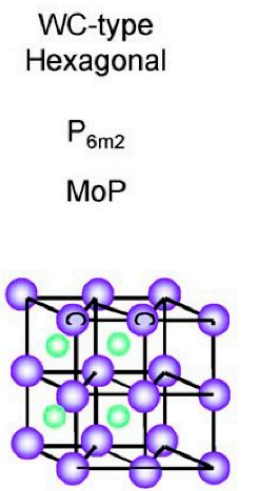

MnP-type Orthorhombic

$D_{2 h}-P_{h n m}$

WP, CrP, MnP, FeP, CoP

$$
\begin{gathered}
\text { NiAs-type } \\
\text { Hexagonal } \\
\mathrm{D}_{6 \mathrm{~h}}^{4}-\mathrm{P}_{3 / \mathrm{mmc}} \\
\text { VP }
\end{gathered}
$$
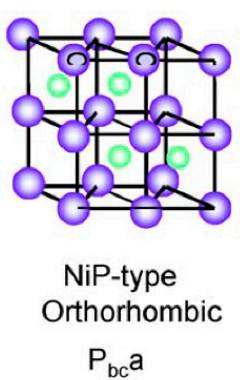

NiP

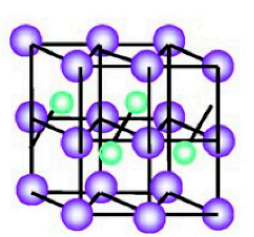

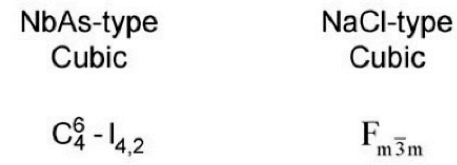

$\beta$-NbP, $\beta$-TaP

UP, ThP, PuP, YP, ZrP
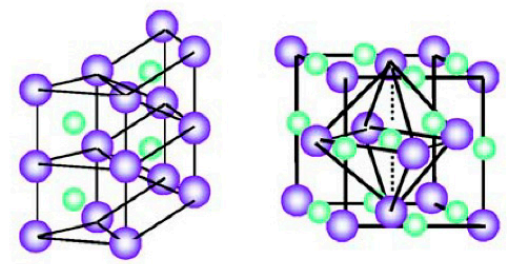

$\mathrm{Fe}_{2} \mathrm{P}$-type

Orthorhombic

$\mathrm{P}_{62 \mathrm{~m}}, \mathrm{D}_{3 \mathrm{~h}}^{2}$

$\mathrm{Ni}_{2} \mathrm{P}, \mathrm{Fe}_{2} \mathrm{P}, \mathrm{Mn}_{2} \mathrm{P}$

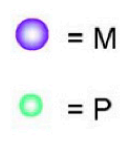

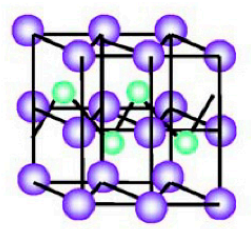

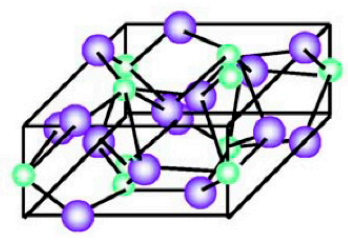

Figure 2. Crystal structures of metal-rich phosphides (Reproduced from the work of [21] with permission). 


\subsection{Preparation of Transition Metal Phosphides}

The literature describes numerous methods for synthesizing TMPs. These methods have been classified into four main groups: solution-phase reactions, gas-solid reactions, solvothermal reactions of $\mathrm{P}$, and other methods.

\subsubsection{Solution-Phase Reactions}

This methodology is based on the liquid phase reaction between a phosphorus source and metal precursors at a high temperature. The phosphorous source is usually a phosphine (tri-n-octylphosphine, tri-phenylphosphine, etc.) or phosphine oxide, while the metal precursors include metal (bulk or nanoparticles), metal acetylacetonates, metal-carbonyl compounds, and coordination compounds of metals or metal oxides [19]. The C-P bond is broken at high temperatures of approximately $300{ }^{\circ} \mathrm{C}$, and the liberated $\mathrm{P}$ reacts with the metal precursor. The use of phosphines favors the reaction because of their strong coordination effects. The use of these high temperatures implies the utilization of organic solvents with a high boiling point, such as $\mathrm{C}_{16}-\mathrm{C}_{20}$ hydrocarbons or amines, and the strict absence of oxygen to avoid the formation of flammable mixtures. These methodologies usually yield metal phosphides in suspension. However, these nanoparticles must be supported in a high surface carrier before use as a heterogeneous catalyst.

This method has been successfully used to prepare silica-supported $\mathrm{Ni}_{2} \mathrm{P}$. As reported in a previous study [8], first, a precursor is obtained by mixing a nickel precursor (nickel acetylacetonate) with a phosphorous precursor (trioctylphosphine in a certain amount of 1-octadecene solvent). These compounds are dissolved by vigorous stirring at $60{ }^{\circ} \mathrm{C}$ under inert. Then, the corresponding amount of support $\left(\mathrm{SiO}_{2}\right.$, in this case) is added to the solution; after $1 \mathrm{~h}$, the temperature is increased to $320-340{ }^{\circ} \mathrm{C}$, also under inert. The reaction takes $2 \mathrm{~h}$, after which the temperature is reduced to $50{ }^{\circ} \mathrm{C}$, and an excess of ethanol added. The obtained solid is filtered. Finally, the filtrate is washed with hexane under ultrasound to remove remaining organics adsorbed on the surface. This cleaning step is repeated at least twice. Afterwards, the sample is dried at $80^{\circ} \mathrm{C}$ overnight. An interesting and elegant alternative is the use of coordination compounds of metals that contain $\mathrm{P}$ and a metal in the same compound that yields metal phosphides nanoparticles in suspension $[25,26]$.

\subsubsection{Gas-Solid Reactions}

Phosphides have been produced in gas-solid reactions. In a first approach, phosphine represents a good option because it is a gas that can yield metal phosphides quite efficiently, but the high toxicity of this gas requires the use of alternatives. For this reason, some compounds that generate $\mathrm{PH}_{3}$ in situ have been employed, such as hypophosphites, phosphites, or phosphates. Hypophosphites decompose at moderate temperatures (approximately $250{ }^{\circ} \mathrm{C}$ ), yielding $\mathrm{PH}_{3}$, which reacts with the metal precursor. However, phosphites $[27,28]$ or phosphates $[8,29]$ require hydrogen to form phosphine. Metals, metal oxides, hydroxides, salts, and other metallic compounds have been used as precursors. The procedure is based on mixing the phosphorous and metal precursor and heating the mixture in the presence of a flow of an inert gas or hydrogen, depending on the phosphorous precursor. The resulting material usually maintains the initial structure of the metal precursor. This procedure is quite appropriate for preparing supported metal phosphides to be used as heterogeneous catalysts, because the metal and phosphorus precursors are mixed and deposited on a high surface carrier and treated to obtain the supported metal phosphides. The synthesis of the supported phosphide catalysts is mainly performed using the following methods: (a) a standard "phosphate method" and (b) a "phosphite method". First, the support is dried and calcined. The first two methods require the preparation of a precursor in three steps. In the "phosphate method", proper amounts of the desired metal salt and ammonium phosphate are mixed and form a solution in distilled water. In the "phosphite method", the phosphorus source is phosphorous acid. Then, the mixed solution is used to impregnate the support through incipient wetness impregnation or wet impregnation. Afterwards, in the "phosphate method", the impregnated 
support is dried and calcined, and in the "phosphite method", the impregnated support is only dried overnight (without calcination). Finally, for both methods, the last stage consists of the reduction of phosphates to phosphides by temperature-programmed reduction reactions. The reduction in temperature depends on the reduction profile, which is independently obtained for the corresponding phosphate impregnated on the support. The reduction reaction is conducted under large hydrogen flow rates to decrease the inhibition of phosphide formation by water vapor produced during this reaction $[8,15]$, as high flow rates favor the quick removal of water formed during the reduction process. This approach will favor the formation of smaller particles and the diffusion of volatile $\mathrm{P}$ species onto nickel particles, promoting phosphide formation. On the other hand, the reduction ramp also influences phosphide formation. As reported in the literature, the intensity and sharpness of the peaks corresponding to the corresponding phase increase as the heating rate decreases, as the crystallinity increases when the time allotted to the formation of this phase increases [27]. However, if the ramp is too low $\left(\sim{ }^{\circ} \mathrm{C} / \mathrm{min}\right)$, another undesirable phase, $\mathrm{Ni}\left(\mathrm{PO}_{3}\right)_{2}$, is formed. Therefore, the optimum reduction ramp should be close to $3^{\circ} \mathrm{C} / \mathrm{min}$. Finally, after the reduction, the reaction must be cooled with $\mathrm{N}_{2}$ and passivated $\left(0.5 \% \mathrm{O}_{2} / \mathrm{N}_{2}\right.$ flow for $\left.2 \mathrm{~h}\right)$ [8] to preserve the obtained composition. Depending on the transition phosphite salt that forms, this reduction reaction can be conducted at high temperatures, according to the strength of the $\mathrm{P}-\mathrm{O}$ bond. These possibly severe conditions reduce the surface area and, consequently, the catalytic activity of the catalysts [30].

The catalytic results obtained from both "phosphate" and "phosphite" methods have been tested with the following catalysts: $\mathrm{Ni}_{2} \mathrm{P}, \mathrm{CoP}, \mathrm{MoP}, \mathrm{FeP}$, and WP. In general, supported catalysts produced using the "phosphite method" display a higher surface area and comparable selectivity towards HDO (hydrodeoxygenation) products at $5 \%$ total conversion. Significant differences in the turnover frequency were not observed, with the exception of the WP catalyst. In this case, the P/W surface ratio is twice the value obtained from the "phosphite method", as this method does not undergo calcination to remove the excess surface phosphorus. This excess phosphorus on the surface affects the HDO reaction pathway [29]. Thus, the phosphorous residues produce a catalyst surface with fewer vacant sites, leading to a step-wise consecutive dehydrogenation.

\subsubsection{Solvothermal Reduction Reactions with Phosphorous}

Metal phosphides can be obtained through a direct reaction of phosphorus $\left(\mathrm{Na}_{3} \mathrm{P}\right.$, red $\mathrm{P}$, or yellow P) with metal precursors. However, the direct reaction is highly exothermic and a solid mixture reaches very high temperatures, yielding materials with poor characteristics. For this reason, this reaction must be conducted in an inert solvent that regulates the reaction rate and reduces the increased temperature. Several metal phosphides have been obtained from a reaction of $\mathrm{Na}_{3} \mathrm{P}$ with metal salts that are soluble in an aromatic solvent (benzene or toluene), $\mathrm{Ni}_{2} \mathrm{P}$ [31], a mixture of $\mathrm{CoP}$ and $\mathrm{Co}_{2} \mathrm{P}$ [32], and $\mathrm{FeP}$ [33] at moderate temperatures $\left(150-200^{\circ} \mathrm{C}\right)$. Halide salts react with yellow $\mathrm{P}$ in toluene [34], but under more harsh conditions than reactions with sodium phosphide. Similar procedures have been performed with red $\mathrm{P}$, but with less strict reaction conditions, such as the presence of water or oxygen [35]. Some authors use basic solutions (ethylenediamine/water, ammonia/water) as the solvent for these reactions [35,36]. The solvothermal method described here cannot be used to synthesize supported metal phosphides, as the material must be prepared and then the solvent must be replaced to incorporate the support.

\subsubsection{Other Synthetic Methods}

Finally, TMPs have been prepared with a large variety of methodologies, including cathodic deposition on a metal substrate [37], the incorporation of metals through ion exchange with P-containing porous ionic polymers, and pyrolysis [38].

\subsection{Catalytic Applications of Transition Metal Phosphides}

Many catalytic applications of TMPs have been described, including electrochemical performance in hydrogen evolution, oxygen evolution reactions or methanol oxidation, photocatalysis, 
hydrotreatments, and so on These applications have been widely reviewed in the literature [17-22,39], and a summary of these applications is presented below (and compiled in Table 1).

Table 1. Different catalytic applications of transition metal phosphides (TMPs). HDO-hydrodeoxygenation; HDS-hydrodesulfurization; HDN-hydrodenitrogenation; HER—hydrogen evolution reaction; OER—oxygen reduction reaction.

\begin{tabular}{|c|c|c|c|c|}
\hline Catalysts & $\begin{array}{l}\text { Catalytic } \\
\text { Application }\end{array}$ & Specific Process & Reactants & Ref. \\
\hline TMPs/alumina & \multirow{4}{*}{ hydrogenation } & & acetylene & [40] \\
\hline Ni phosphide & & & butadiene & {$[41,42]$} \\
\hline Mo phosphide & & & acetonitrile & {$[43]$} \\
\hline Ni phosphide/silica & & & naphtalene & {$[44]$} \\
\hline $\mathrm{Ni}_{2} \mathrm{P} / \mathrm{SiO}_{2}$ & \multirow{9}{*}{ hydrotreatment } & HDS, HDN, HDO & $\begin{array}{l}\text { dibenzothiophene, } \\
\text { quinoline, benzofuran }\end{array}$ & [14] \\
\hline $\begin{array}{c}\mathrm{Co}_{2} \mathrm{P}, \mathrm{Ni}_{2} \mathrm{P}, \mathrm{MoP}, \mathrm{WP}, \mathrm{CoMoP}, \\
\mathrm{NiMoP}\end{array}$ & & HDN & & [16] \\
\hline TMPs & & HDS/HDN & review & [18] \\
\hline TMPs & & HDS/HDN & review & [21] \\
\hline $\begin{array}{c}\mathrm{Fe}_{2} \mathrm{P}, \mathrm{CoP}, \mathrm{MoP}, \mathrm{WP}, \mathrm{Ni}_{2} \mathrm{P} \\
\text { supported on } \mathrm{SiO}_{2}\end{array}$ & & HDS/HDN & dibenzotiophene/quinoline & [22] \\
\hline WP & & HDS/HDN & dibenzotiophene/quinoline & [28] \\
\hline $\mathrm{Ni}_{2} \mathrm{P} / \mathrm{SiO}_{2}$ & & HDS/HDN & $\begin{array}{l}\text { dimethyldibenzotiophene, } \\
\text { dimethylsulfide, quinoline }\end{array}$ & [45] \\
\hline $\mathrm{Ni}_{2} \mathrm{P} / \mathrm{SiO}_{2}$ or MCM- 41 & & HDS & dimethyldibenzotiophene & [46] \\
\hline $\mathrm{Fe}_{2} \mathrm{P}, \mathrm{CoP}, \mathrm{Ni}_{2} \mathrm{P} / \mathrm{SiO}_{2}$ & & HDS/HDN & $\begin{array}{l}\text { quinoline/dibenzotiophene/ } \\
\text { benzofuran/tetralin/tetradecane }\end{array}$ & {$[47]$} \\
\hline TMPs & \multirow{12}{*}{ electrochemistry } & $\begin{array}{l}\text { (HER, OER, methanol } \\
\text { oxidation, photocatalysts } \\
\text { for } \mathrm{H}_{2} \mathrm{O} \text { splitting) }\end{array}$ & Review-energy conversion & [20] \\
\hline $\mathrm{Ni}_{2} \mathrm{P}$ & & \multirow{5}{*}{ HER } & \multirow{5}{*}{ hydrogen } & [48] \\
\hline $\mathrm{Ni}-\mathrm{Co}-\mathrm{P}$ & & & & [49] \\
\hline $\mathrm{CoP} / \mathrm{Ni}_{5} \mathrm{P}_{4}$ & & & & [50] \\
\hline CoxP & & & & [51] \\
\hline $\mathrm{CoP}$ & & & & [55] \\
\hline $\mathrm{CoP}$ & & \multirow{3}{*}{ OER } & \multirow{3}{*}{ oxygen } & [55] \\
\hline $\mathrm{Co}_{2} \mathrm{P}$ & & & & [56] \\
\hline Co phosphide & & & & [57] \\
\hline $\mathrm{Ni}_{2} \mathrm{P}$ & & \multirow{3}{*}{ Methanol oxidation } & \multirow{3}{*}{ methanol } & [52] \\
\hline $\mathrm{Pt}-\mathrm{CoP} / \mathrm{C}$ & & & & [53] \\
\hline $\mathrm{MoP}$ & & & & [54] \\
\hline $\mathrm{Ni}_{\mathrm{x}} \mathrm{P}$ & \multirow{5}{*}{$\begin{array}{l}\text { cocatalysts in } \\
\text { photocatalysis }\end{array}$} & \multirow{5}{*}{$\mathrm{H}_{2} \mathrm{O}$ splitting } & \multirow{5}{*}{$\mathrm{H}_{2} \mathrm{O}$} & [58] \\
\hline $\mathrm{Cu}_{3} \mathrm{P} / \mathrm{g}-\mathrm{C}_{3} \mathrm{~N}_{4}$ & & & & [59] \\
\hline Co phosphide $/ \mathrm{Zn}_{0.5} \mathrm{Cd}_{0.5} \mathrm{~S}$ & & & & [60] \\
\hline Fe phosphide/g- $C_{3} N_{4}$ & & & & [61] \\
\hline $\mathrm{NiCoP} / \mathrm{g}-\mathrm{C}_{3} \mathrm{~N}_{4}$ & & & & [62] \\
\hline
\end{tabular}

\subsubsection{Hydrogenation and Hydrotreatments}

Transition metal phosphides are active in several hydrogenation and hydrotreatment reactions including, among others, HDS (hydrodesulfurization), HDN (hydrodenitrogenation), HDO (hydrodeoxygenation), hydrogenation, and hydrogenolysis (bond breaking) reactions. The properties of several TMP close to metals make them potential catalysts in hydrogenation and hydrotreatments. TMPs are able to catalyze the hydrogenation of acetylene to ethylene [40]; butadiene to butane [41,42], 
acetonitrile [43], or naphthalene [44]; and are active catalysts in hydrodesulfurization (HDS) and hydrodenitrogenation (HDN) reactions $[14,16,18,21,22,28,45-47]$. The current main applications using bio-oil HDO catalysts $[18,20]$ and the hydrotreatment of vegetable and algae oil will be extensively discussed in the subsequent sections.

\subsubsection{Electrochemical Performance}

TMPs have been employed as alternative electrocatalysts to noble metals $(\mathrm{Pt})$ in the electrochemical hydrogen evolution reaction (HER), with interesting results obtained in alkaline and acidic media. The electro-catalytic performance of transition metal phosphides is excellent. Among them, the catalytic performance of bimetallic phosphides, CoNiP, for instance, is usually better than that of their single transition metal phosphides counterparts. In addition, some other strategies to improve the performance include the use doping with other elements, including metallic and nonmetallic elements [20,48-51].

The inclusion of TMPs in the $C$ support enhances the electrochemical methanol oxidation reaction not only in monometallic catalysts, but also in bimetallic systems; this effect implies a reduction in the cost of these electrode materials [20,52-55]. In some cases, the use of TMPs has been proposed as an alternative to noble metals, as the performance is excellent in some cases, but in-depth studies in this field are necessary [20].

TMPs are also used in the electrochemical oxygen reduction reaction (OER) in alkaline media, showing a good performance and high stability [20,55-57]. This behavior is particularly enhanced by the combination with nitrogen-doped carbons [20,57]. The catalytic behavior of Co-based phosphides is comparable to $\mathrm{Pt} / \mathrm{C}$, and in some cases, TMPs have better performance than precious metal-based catalysts.

\subsubsection{Photocatalysis}

TMPs $(\mathrm{Fe}, \mathrm{Co}, \mathrm{Ni}$, and $\mathrm{Cu}$ ) have been employed as cocatalysts in the water splitting reaction to generate hydrogen in combination with the traditional catalysts $\mathrm{CdS}$ or $\mathrm{g}-\mathrm{C}_{3} \mathrm{~N}_{4}$; the use of TMPs as cocatalysts produces an substantial increase in the hydrogen evolution rate [20,58-62]. Many researchers have focused on studying monometallic phosphides, with bimetallic phosphides and element-doped phosphides receiving less attention. Therefore, a wide field remains to be explored to further improve photocatalysis.

\section{Green Diesel Production through the HDO of Nonedible Oils}

\subsection{Feed Source and Composition: Model Compounds as Reactants}

In HDO reactions, vegetable oils produce hydrocarbons. The HDO of vegetable oil consumes large amounts of hydrogen and such an amount depends on the nature of the oil precursor and the kinetics and mechanism of the reaction. It is obvious that highly saturated feedstocks such as palm oil offer less $\mathrm{H}_{2}$-consumption than other unsaturated oil precursors. For instance, camelina oil contains a relatively large amount of unsaturated fatty acid chains $(27 \%-40 \% \mathrm{C} 18: 3)$ [63] and has been used to produce jet fuels. Algal oils may also contain large amounts of n-heptadecane unsaturated chains [64] and, for this reason, have also been used as oil precursor for aviation [65]. Therefore, the direct conversion of vegetable oils via hydrogenation to produce liquid fuel for transportation appears to be the optimal choice [66]. The process for producing hydrocarbons for diesel fuel components based on HDO has been developed and commercialized by Neste Oil, UOP/ENI, and Haldor-Topsoe, among other companies [67].

Typically, the products obtained from the hydrogenation of triglycerides are n-alkanes, and by-products such as propane, water, $\mathrm{CO}$, and $\mathrm{CO}_{2}$ [68]. Hydrogenation of unsaturated feedstocks results in one less or the same number of carbons than in the $C_{18}$ original chains. In the complete hydrogenation of triglycerides, the resulting hydrocarbons can be formed either by 
hydrodeoxygenation (HDO) or by hydrodecarboxylation (HDC). HDO reactions produce n-alkanes with the same carbon number (even C-number) as the original fatty acid chain with water and propane byproducts. If reaction pathway is $\mathrm{HDC}$, hydrocarbons contain one $\mathrm{C}$-atom less than the original chain (odd $\mathrm{C}$-number) with $\mathrm{CO}, \mathrm{CO}_{2}$, and propane by-products.

\subsection{Hydrotreatment Reactions}

The technology for producing diesel fuel from vegetable oil has been developed for the production of FAME or biodiesel [69]. While FAME has a high cetane number, it has a poor stability and high solvency, leading to filter fouling problems. These issues have been overcome by the development of a different hydroprocessing route that is able to produce a high quality diesel fuel that is completely compatible with the existing refinery infrastructure and fuel distribution network.

Hydroprocessing is one catalytic process in a refinery that comprises a group of heterogeneously catalyzed reactions for which bifunctional catalysts (metal and acidic functions) are used. Hydroprocessing transforms a variety of oil fractions into clean transportation fuels. The reactions involved in hydroprocessing include (i) hydrocracking and (ii) hydrotreating. The production of green diesel and jet fuel from vegetable oils is considered technically feasible via a relatively simple and flexible hydrotreatment process. The whole hydrodeoxygenation (HDO) process consists of breaking the $\mathrm{C}-\mathrm{O}$ bond to yield carboxylic acids that are transformed into hydrocarbons via the removal of the oxygen atom. Oxygen is removed from each carboxylic acid molecule by one of three reactions to form hydrocarbon chains. These reactions pathways include hydrodecarboxylation $\left(\mathrm{HDCO}_{2}\right)$, hydrodecarbonylation (HDCO), and hydrodewatering (HDW). The $\mathrm{HDCO}_{2}$ pathway (Equation (1)) involves the conversion of a carboxylic acid group into an alkane and carbon dioxide when no hydrogen molecule is being consumed. In the HDCO pathway (Equation (2)), a carbon monoxide, one molecule of water, and a carbon chain are produced through the consumption of one $\mathrm{H}_{2}$ molecule. The HDW pathway (Equation (3)) involves the production of two water molecules and a carbon chain with the consumption of three hydrogen molecules. In the first two pathways, the product chain is one $\mathrm{C}$-atom shorter than the product chain from the HDW reaction, because of the production of either carbon monoxide or carbon dioxide. The HDO reaction provides a high rate of conversion of vegetable oils to middle distillate paraffins, which have been used as an alternative diesel fuel:

$$
\begin{array}{cc}
\mathrm{HDCO}_{2}: & \mathrm{R}-\mathrm{COO}-\mathrm{R}^{\prime}+\mathrm{H}_{2} \rightarrow \mathrm{R}-\mathrm{H}+\mathrm{R}^{\prime}-\mathrm{H}+\mathrm{CO}_{2}, \\
\text { HDCO: } & \mathrm{R}-\mathrm{COO}-\mathrm{R}^{\prime}+2 \mathrm{H}_{2} \rightarrow \mathrm{R}-\mathrm{H}+\mathrm{R}^{\prime}-\mathrm{H}+\mathrm{CO}+\mathrm{H}_{2} \mathrm{O}, \\
\text { HDW: } & \text { R-COO-R' }+3 \mathrm{H}_{2} \rightarrow \mathrm{R}-\mathrm{H}+\mathrm{R}^{\prime}-\mathrm{H}+2 \mathrm{H}_{2} \mathrm{O} .
\end{array}
$$

The reaction pathway used to form hydrocarbons depends on the catalyst and the reaction conditions (temperature and hydrogen pressure) (see the works of [70,71]). Hydrogen flow is essential in hydrotreatment of vegetable oils because $\mathrm{H}_{2}$ acts not only as a reactant, but also in assisting with the removal of water by-product from the catalyst surface, thereby preventing deactivation. Temperature exerts the most important effect on hydrotreatment, particularly on the product yields. At low temperatures, oxygen removal is limited, whereas at higher temperatures, oxygen removal is enhanced. However, as the temperature increases, diesel products decrease, which is consistent with the appearance of hydrocracking reactions. As the temperature of the hydrotreatment reaction increases, diesel selectivity gradually decreases. However, higher reactor temperatures are required to improve reaction rates. A lower reaction temperature favors the $\mathrm{HDW}$ pathway. Therefore, $\mathrm{HDCO}_{2}$ offers the advantages of lower hydrogen consumption than the other two pathways.

In addition to hydrotreatment reactions, hydrocracking reactions usually occur. Hydrocracking involves destructive hydrogenation and is characterized by the conversion of large molecules through $\mathrm{C}-\mathrm{C}$ bond breaking into lighter products. Isomerization also takes place with the subsequent production of gasoline and diesel range hydrocarbons. These reactions require high $\mathrm{H}_{2}$ pressures 
and moderately high reaction temperatures to minimize chain polymerization reactions that lead to coke deposits on the catalyst surface [72]. Hydrocracking is performed on acid supports such as $\mathrm{SiO}_{2}-\mathrm{Al}_{2} \mathrm{O}_{3}$, crystalline zeolites (ZSM-5, HY), silica-alumina-phosphates (SAPO), and ordered mesoporous silicas (SBA-15, MCM-41) [73]. All these substrates develop high activity in target reactions when a hydrogenation phase is incorporated on their surface [74].

\subsection{Catalysts for Green Diesel Production}

Many catalysts have been studied for bio-oils and waste oils/fats upgrading, ranging from carbides, nitrides, and phosphides to supported transition metals, but despite these different hydrogenation phases, the most common promising catalysts are bifunctional; they contain an hydrogenation function and an acid function. In this contribution, we review phosphide catalysts that are currently used for HDO.

Transition metal phosphides were only recently studied for HDO reactions, including FeP [75], $\mathrm{CoP}[75], \mathrm{Ni}_{2} \mathrm{P}[14,75,76], \mathrm{MoP}[75,77], \mathrm{WP}[75]$, and $\mathrm{Ru}_{2} \mathrm{P}$ [78]. The main active phases for these metal phosphides during $\mathrm{HDO}$ are $\mathrm{M}^{\delta+}(\mathrm{M}$ is a transition metal with a small positive charge) and Brønsted sites [77]. $\mathrm{M}^{\delta+}$ functions as a Lewis acid site and participates in hydrogenation, hydrogenolysis, and demethylation reactions [79]. Partial reduction of the phosphate precursors leads to the formation of Brønsted sites (PO-H) [77], in which active hydrogen species are formed, although these H-species are less active than those produced at metal sites. MoP shows bifunctional character as it displays acidity and hydrogenation capabilities that are similar to those of noble metals deposited on acidic supports [80]. The mechanism of HDO using TMPs is proposed in Figure 3, and is based on the literature $[75,77]$. Oxy compounds and adsorbed $\mathrm{H}_{2}$ are activated on the $\mathrm{M}^{\delta+}$ sites, and $\mathrm{H}$-atoms from both $\mathrm{M}^{\delta+}$ sites and Brønsted $\mathrm{PO}-\mathrm{H}$ sites react with the adsorbed oxy intermediate species to produce deoxygenated products.

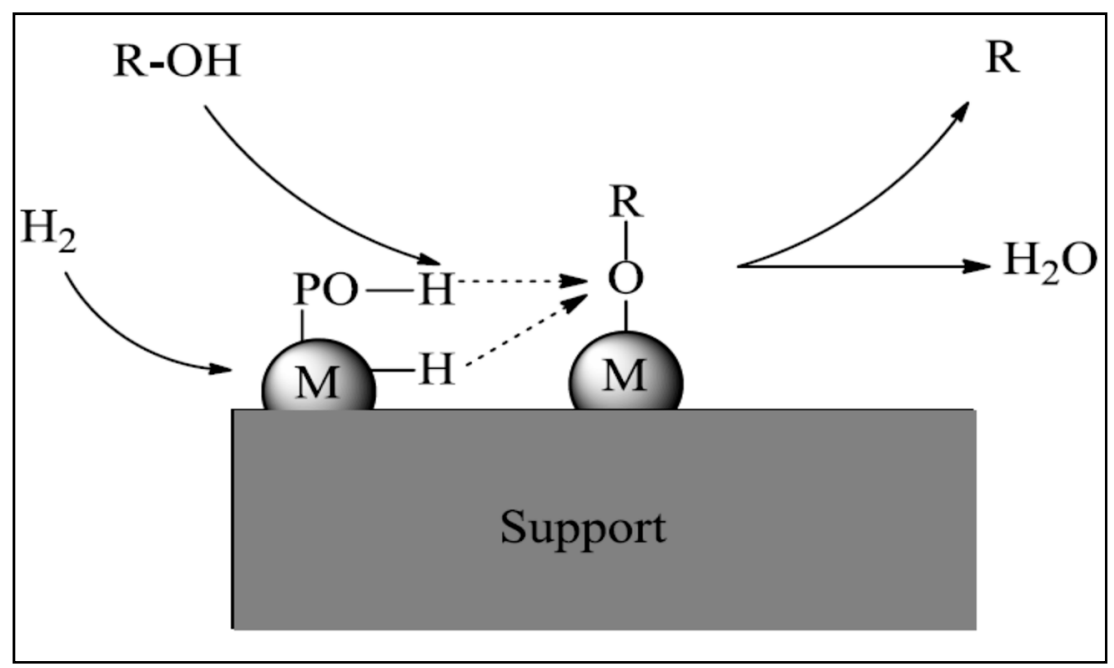

Figure 3. Proposed hydrodeoxygenation (HDO) mechanism using supported transition metal phosphides. Reproduced with permission from the authors of [77].

The HDO activity of guaiacol model compound was investigated by Oyama [81] using different phosphides supported on silica, in a fixed bed at $300{ }^{\circ} \mathrm{C}$ and atmospheric pressure. The results in sequence were as follows: $\mathrm{Ni}_{2} \mathrm{P}>\mathrm{Co}_{2} \mathrm{P}>\mathrm{Fe}_{2} \mathrm{P}>\mathrm{WP}>\mathrm{MoP}$. As the cost of these phosphides is much lower than that of noble metals, and taking into account their high activity, TMPs are attractive for bio-oil HDO processes. However, one of the disadvantages of phosphides is that they become oxidized by $\mathrm{H}_{2} \mathrm{O}$ and may result in the formation of metal oxides or phosphates with the subsequent catalyst deactivation. 
The initial Ni/P molar ratio exerts a strong influence on the speciation and, therefore, on the performance of the supported nickel phosphide catalysts [82,83]. As reported by Stinner et al. [84], an $\mathrm{Ni} / \mathrm{P}$ molar ratio equal to 2 results in the formation of $\mathrm{Ni}_{12} \mathrm{P}_{5}$ and $\mathrm{Ni}_{3} \mathrm{P}$ phases over silica, an $\mathrm{Ni} / \mathrm{P}$ molar ratio equal to 1.7 results in the formation of $\mathrm{Ni}_{12} \mathrm{P}_{5}$ and $\mathrm{Ni}_{2} \mathrm{P}$ phases, and an $\mathrm{Ni} / \mathrm{P}$ molar ratio $=1.5$ only favors the formation of the $\mathrm{Ni}_{2} \mathrm{P}$ phase. In another study, Chen et al. [82] studied the silica-supported nickel phosphide catalysts with different $\mathrm{Ni} / \mathrm{P}$ molar ratios in methyl laurate HDO, and they found the following activity trend:

$$
\mathrm{Ni}_{3} \mathrm{P}(\mathrm{Ni} / \mathrm{P}=3 / 1)<\mathrm{Ni}_{12} \mathrm{P}_{5}(\mathrm{Ni} / \mathrm{P}=2 / 1)<\mathrm{Ni}_{2} \mathrm{P}(\mathrm{Ni} / \mathrm{P}=1 / 1 \text { and } 1 / 2) \approx \mathrm{Ni} \text {. }
$$

\subsection{HDO Performance Using Transition Metal Phosphide Catalysts}

The nature of the support exerts a strong effect on the reactivity of nickel phosphide catalysts. Shi et al. [85] reported the HDO reaction of methyl laurate on different catalysts to yield $C_{11}$ and $C_{12}$ hydrocarbons over nickel phosphide catalysts supported on $\mathrm{SiO}_{2}, \mathrm{CeO}_{2}, \mathrm{TiO}_{2}, \mathrm{SAPO}-11, \gamma-\mathrm{Al}_{2} \mathrm{O}_{3}$, and $\mathrm{HY}$ zeolite, which were prepared with an Ni/P ratio of 1.0. Figure $4 \mathrm{~A}$ shows the conversion of methyl laurate using different catalysts. As the temperature increased from 573 to $613 \mathrm{~K}$, the conversion also increased on all catalysts. At every temperature, $\mathrm{Ni}_{2} \mathrm{P} / \mathrm{SiO}_{2}$ produced the highest conversion rate. The activities of the catalysts were very different as the temperature increased. The supports exerted an important effect on the catalyst activity. Surprisingly, $\mathrm{Ni}_{2} \mathrm{P} / \mathrm{SiO}_{2}$ produced the highest conversion rate, which is related to the lower support effect of $\mathrm{SiO}_{2}$ due to the reduced acidity or reducibility compared with other supports.

(A)

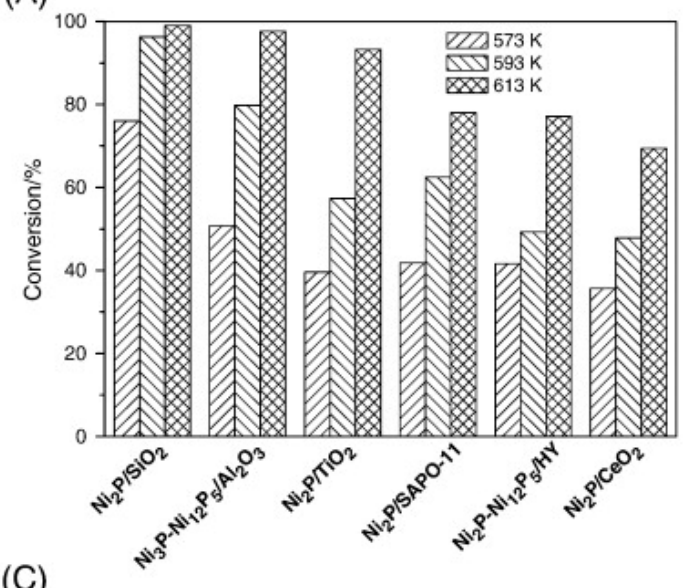

(C)

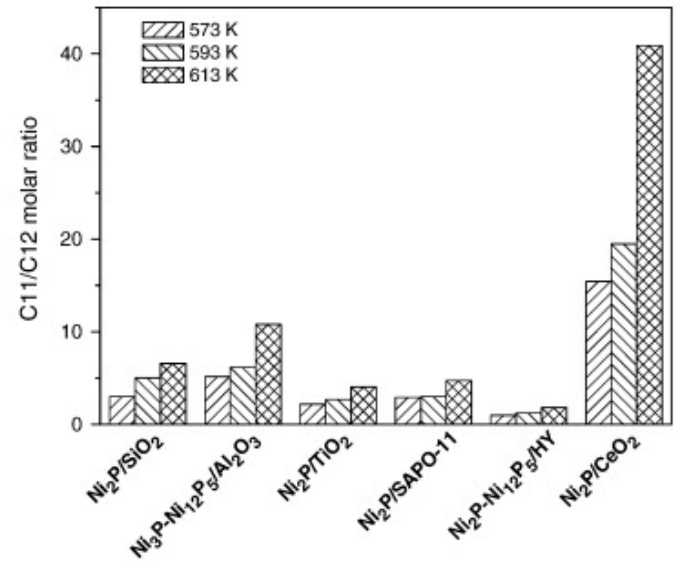

(B)

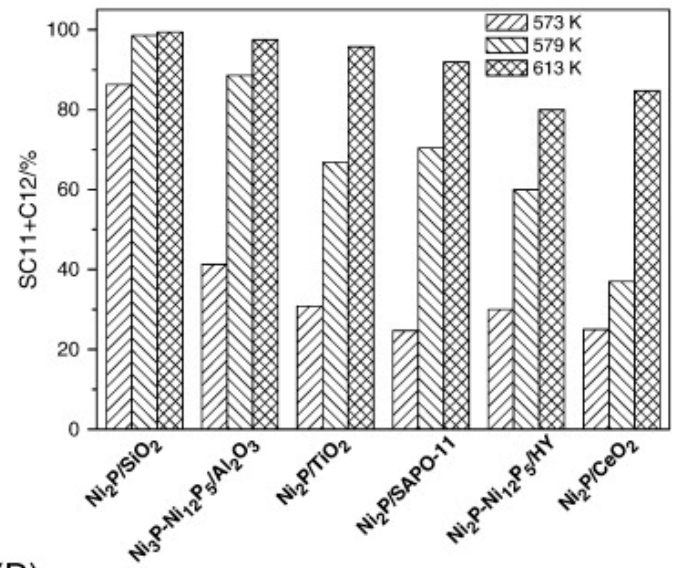

(D)

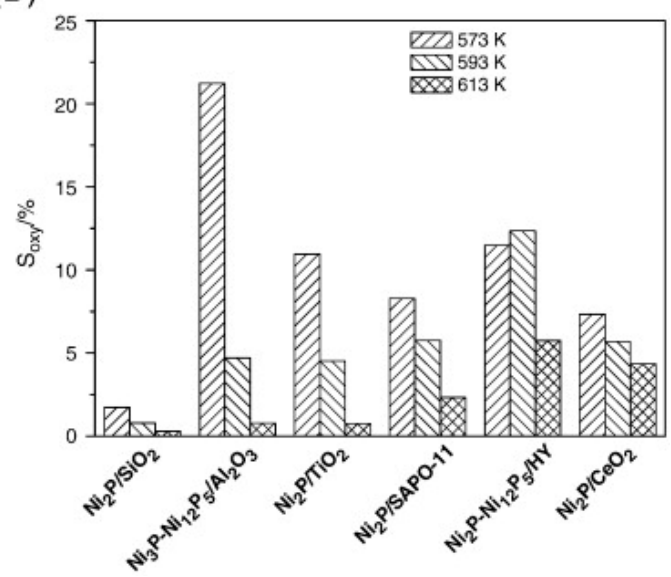

Figure 4. Deoxygenation of methyl laurate using different catalysts. Reaction conditions: $\mathrm{H}_{2}$ pressure $=$ $2.0 \mathrm{MPa}, \mathrm{WHSV}=10 \mathrm{~h}, \mathrm{H}_{2} /$ methyl laurate molar ratio $=50$. (Reproduced with permission from Elsevier Science Publishers [85]). 
Figure $4 \mathrm{~B}$ shows the total selectivity for $\mathrm{C}_{11}$ and $\mathrm{C}_{12}$ hydrocarbons of different catalysts. As the temperature increased, $\mathrm{S}\left(\mathrm{C}_{11}+\mathrm{C}_{12}\right)$ increased for all catalysts. The catalyst with a higher conversion rate also produced a higher $S\left(C_{11}+C_{12}\right)$. As shown in Figure $4 C$, the $C_{11} / C_{12}$ molar ratios were strongly influenced by the catalysts. The HDO of methyl laurate was found to follow the decarbonylation and $\mathrm{HDO}$ routes. As the $\mathrm{C}_{11} / \mathrm{C}_{12}$ molar ratio represents the selectivity between the decarbonylation and $\mathrm{HDO}$ pathways, the higher $\mathrm{C}_{11} / \mathrm{C}_{12}$ molar ratio indicates that the decarbonylation reaction is dominant. Increasing the reaction temperature, the $C_{11} / C_{12}$ molar ratio increased on all catalysts, thus the temperature increasing favors the activation of the decarbonylation pathway.

The total selectivity $\left(\mathrm{S}_{\text {oxy }}\right)$ of the oxygenated intermediates (alcohol, aldehyde, acid, and ester) is shown in Figure 4D. With the exception of $\mathrm{Ni}_{3} \mathrm{P}-\mathrm{Ni}_{12} \mathrm{P}_{5} / \mathrm{Al}_{2} \mathrm{O}_{3}$ and $\mathrm{Ni}_{2} \mathrm{P}-\mathrm{Ni}_{12} \mathrm{P}_{5} / \mathrm{HY}$, which produced higher $\mathrm{S}_{\text {oxy }}$ values than the other catalysts at lower temperatures, the catalysts with higher activity tended to exhibit lower selectivity towards the oxygenated intermediates. The O-containing intermediates were further deoxygenated in the course of the reaction via HDO or decarbonylation. These results correlate with the surface density of Ni sites, the electron property of the Ni site, the size of the crystalline $\mathrm{Ni}_{2} \mathrm{P}$, and the synergism between the $\mathrm{Ni}$ site and the acid site or the oxygen vacancy.

\subsection{Reaction Network}

The reaction network was explored by selecting a convenient surrogate for triglyceride molecules. For example, the hydrotreatment of methyl laureate $\left(\mathrm{C}_{11} \mathrm{H}_{23}-\mathrm{COO}-\mathrm{CH}_{3}\right)$ in a fixed-bed continuous flow reaction yields n-alkanes as the main products [86]. This HDO reaction was performed at 573-613 $\mathrm{K}$ and an overall pressure of $2.0 \mathrm{MPa}$ on $\mathrm{Ni}_{2} \mathrm{P} / \mathrm{SiO}_{2}$ catalysts. For these catalysts, the gas-phase included $\mathrm{CO}$ and $\mathrm{CH}_{4}$, while the liquid phase comprised n-undecane (n- $\left.\mathrm{C}_{11}\right)$, n-dodecane (n- $\left.\mathrm{C}_{12}\right)$, oxygenated intermediates (lauryl alcohol, lauraldehyde, lauric acid, and lauryl laurate), methanol, and cracked hydrocarbons. Small amounts of a light yellow insoluble product in the liquid phase (polymeric components) were observed, but they were undetectable in the GC (Gas Chromatograph) analysis.

The effect of WHSV (weight hourly space velocity) on the performance of the $\mathrm{Ni}_{2} \mathrm{P} / \mathrm{SiO}_{2}$ catalyst was examined to explore the reaction pathway, and the relationship between the methyl laurate conversion and the selectivities towards different products was reported [86]. Upon decreasing the LHSV (liquid hourly space velocity), the conversion and the selectivity towards $C_{11}$ and $C_{12}$ increased, while the selectivity towards lauric acid, lauryl alcohol, and lauryl laurate decreased. Thus, $\mathrm{C}_{11}$ and $\mathrm{C}_{12}$ appear as final products of the HDO reaction, while lauric acid, lauryl alcohol, and lauryl laurate were found to be intermediates. Taking into account that the selectivity towards lauraldehyde is almost constant, it should also be considered as an intermediate. On the basis of this behavior, lauraldehyde is highly reactive and easily converted into other products. In the course of the reaction, the primary products may include lauric acid and lauraldehyde. Lauric acid is produced via hydrogenolysis (reaction a) and/or hydrolysis (reaction b), while lauraldehyde is produced via hydrogenolysis (reaction c) (Figure 5) [87]. The reaction network may include several consecutive reactions: methyl laurate $\rightarrow$ lauric acid $\rightarrow$ lauraldehyde $\rightarrow$ lauryl alcohol $\rightarrow \mathrm{C}_{12}$, in which lauraldehyde is also a secondary product. Laurate acid and lauraldehyde are also converted to $C_{11}$ via decarbonylation [88]. The decarbonylation of the ester is easier than the that of the corresponding acid [88]. Consistent with this finding, the direct decarbonylation of methyl laurate to $\mathrm{C}_{11}$ (reaction $\mathrm{d}$ ) cannot be precluded. The appearance of methanol in the reaction products indicates that reactions $b-\mathrm{d}$ occur. As no $\mathrm{CO}_{2}$ was observed in the gaseous phase and the moles of $\mathrm{CO}$ produced were similar $n-\mathrm{C}_{11}$ at different temperatures, it is inferred that $n-C_{11}$ is produced from the decarbonylation of methyl laurate. $\mathrm{CO}_{2}$ hydrogenation was also studied on the $\mathrm{Ni}_{2} \mathrm{P} / \mathrm{SiO}_{2}$ catalysts to verify that decarbonylation did not occur, and results showed a very low activity, even at the highest reaction temperature $(613 \mathrm{~K})$. Moreover, lauryl laurate was produced by the esterification of lauric acid with lauryl alcohol on acid sites. Thus, it appears that HDO of lauryl laurate is deoxygenated through a similar mechanism to methyl laurate. 
It has been proposed $[89,90]$ that methyl palmitate conversion proceeds through the formation of palmitic acid or hexadecanal as a primary intermediate (Figure 5). Direct hydrogenolysis of the $\mathrm{C}-\mathrm{O}$ bond of the methyl palmitate carboxylic group leads to the formation of hexadecanal and methanol. The hydrolysis of the methyl palmitate only requires the acid functionality. As no $\mathrm{CO}_{2}$ appeared in the exit gas, palmitic acid does not produce $\mathrm{C}_{15}$ hydrocarbons via decarbonylation. Further hydrogenation of this acid likely produces hexadecanal, which is then hydrogenated to pentadecane and pentadecene through a decarbonylation reaction or hexadecanol via hydrogenation.

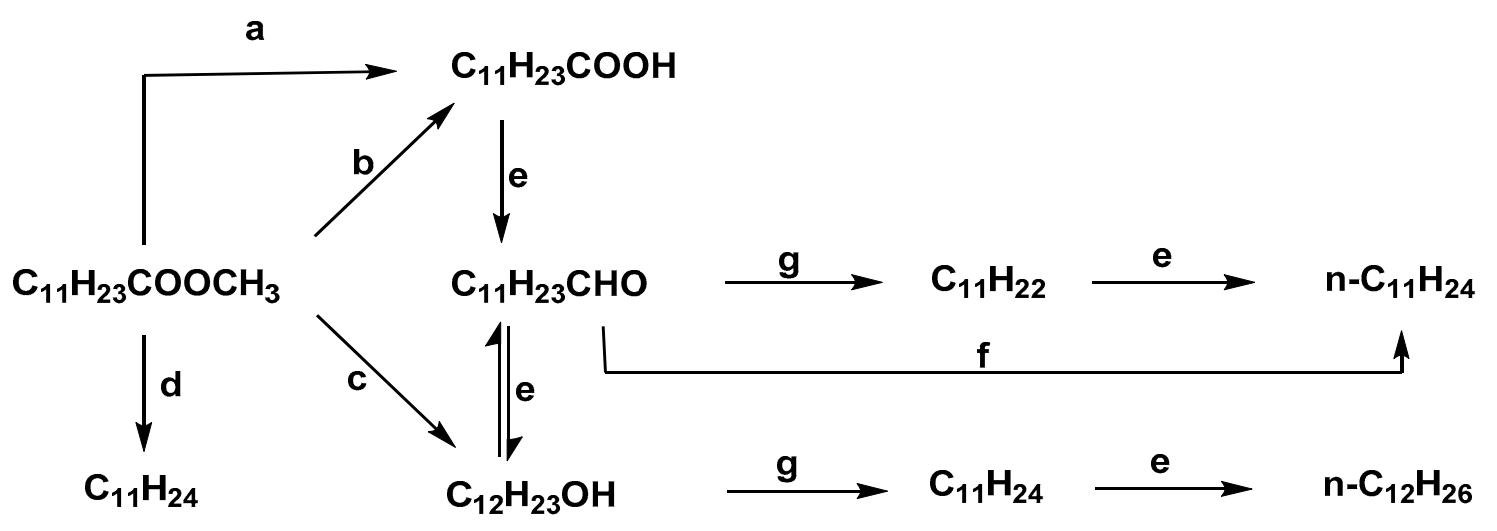

\section{$\mathrm{C}_{11} \mathrm{H}_{23} \mathrm{COOH}+\mathrm{C}_{12} \mathrm{H}_{25} \mathrm{OH} \longrightarrow \mathrm{C}_{11} \mathrm{H}_{23} \mathrm{COOC}_{12} \mathrm{H}_{25}$}

Figure 5. Tentative reaction network of methyl palmitate HDO over silica-supported nickel phosphide catalysts adapted from the work of [87].

\subsection{Deactivation and Regeneration of HDO Catalysts}

During the HDO reactions of the convenient surrogate of triglyceride molecules present in vegetable oils, the catalysts become deactivated and hence activity drops progressively. If catalysts possess some acidity, cracking reactions of alkyl chains of triglyceride molecules occur through many side reactions, following which the subsequent formation of coke occurs. Coke formation is a main factor of catalyst deactivation [91]. Coke deposition on the active sites affects not only the catalyst activity, but also the catalyst selectivity when deposited inside the catalyst pores. The extent and nature of coke deposits depend on the pore size, pore shape, and crystallite size [92]. Other possible sources of catalyst deactivation include active metal leaching and sintering and/or poisoning [93], both processes decrease the number of active sites. Surface oxidation is another possible source of catalyst deactivation. It has been proposed that the phosphorus in $\mathrm{Ni}_{2} \mathrm{P}$ is oxidized to phosphate, which may block the active Ni sites and, subsequently, deactivation occurs [75]. According to density functional theory (DFT) calculations, it has been shown that oxygen on a $\mathrm{Ni}_{2} \mathrm{P}$ surface preferentially interacts with phosphorus [94], which would be the species likely produced by unphosphided present on the $\mathrm{Ni}_{2} \mathrm{P}$ surface. These unphosphided $\mathrm{Ni}^{\delta+}$ sites appear to be responsible for phenol production during guaiacol $\mathrm{HDO}$ reactions [95]. In parallel, the $\mathrm{P} / \mathrm{Ni}$ ratio of the phosphide tends to decrease during the reaction, indicating a drop in the amount of Brønsted acid sites (i.e., $\mathrm{P}-\mathrm{OH}$ ) on the catalyst surface, with an increase in the production of phenol by suppressing its dehydroxylation. Because of the $\mathrm{C}\left(\mathrm{sp}^{2}\right)-\mathrm{OH}$ bond strength in the phenol molecule, the phenol HDO requires the partial hydrogenation of the benzene ring near the $\mathrm{C}\left(\mathrm{sp}^{2}\right)-\mathrm{OH}$ bond [95]. Brønsted acid sites close to a metal site, such as $\mathrm{Ni}$ [96], might facilitate the HDO reaction by protonating the oxygen in phenol molecule.

In summary, although coke deposition and sintering are major sources of the deactivation of $\mathrm{Ni}_{2} \mathrm{P}$ catalysts in HDO reactions, the loss of Brønsted acidity in guaiacol HDO reactions also contributes to catalyst deactivation, particularly regarding changes in product distribution. 
Once the used catalysts are deactivated, regeneration is one of the promising pathways to remove coke deposits from deactivated catalysts. Coke deposits at the surface of deactivated catalysts are removed by calcination under an oxidant atmosphere (i.e., air) at high temperatures $\left(500-600{ }^{\circ} \mathrm{C}\right.$ ). In general, continued regeneration (a few cycles) gradually decreases the catalyst activity. Prolonged reaction-regeneration cycles may result in the disappearance of a large amount of acid sites, and hence activity deteriorates [97]. Josl et al. [98] regenerated used zeolite catalysts at $300{ }^{\circ} \mathrm{C}$ under an $\mathrm{H}_{2}$ stream at 15 bar and concluded that the activity of the zeolite was completely recovered, although regeneration via oxidation appeared as a more efficient reactivation methodology. During oxidative treatment of used catalysts at high temperatures processes, such catalyst destruction and dealumination, as well as the agglomeration of doped metals, may occur. Oxidation and/or reduction (with $\mathrm{H}_{2}$ ) of a deactivated Ni-zeolite catalyst is a successful regeneration process, because it increases the acidity and activity [99].

In summary, the suitable regeneration of used catalysts will likely help reduce the cost of biofuel production from vegetable oil upgrading. The development of highly active catalysts, optimization of oil upgrading technologies, and improvements in reactor system stability are important factors that may reduce the cost.

\section{Catalysts Based on Metal Phosphides for HDO}

Currently, interest in hydrodeoxygenation (HDO) processes focused on removing oxygen from different compounds, particularly waste oils and fats biomass, such as lignocellulose-derived pyrolysis oils, is increasing. The upgrading of these oils would allow them to be used as renewable fuels (called, as indicated above, "green diesel or renewable diesel"), with characteristics that are even better than those of a fossil diesel. Catalytic applications of metal phosphides for HDO, which potentially show higher activity than noble metal catalysts and are much cheaper, as mentioned above, originated from their previous use in other hydrogenation reactions, such as HDS and HDN, since the 1990s [12].

During the last decade, metal phosphide catalysts have been reported to be active in HDO reactions of bio-oils (e.g., guaiacol, 4-methylphenol, anisole, and dibenzofuran) and alkyl esters, which are one of the main compounds in waste oils, such as methyl oleate, methyl laurate, and so on $[12,86,100]$. Among other formulations based on supported transition metal sulfides, noble metals, and non-noble metals (including base metals, metal oxides, borides, carbides, and nitrides), metal phosphides have shown high activity and selectivity for HDO of model compounds existing in bio-oils and waste oils, as well as in real bio-oil and waste oil feeds [100].

As stated above, the HDO reactions of bio-oils require both metal sites for hydrogenation and acid sites for hydrolysis, dehydration, and isomerization. When the catalyst is based on a TMP, it would be the active phase for hydrogenation, although this type of catalyst also possesses a bifunctional nature, as TMPs present acid properties originating from $\mathrm{P}-\mathrm{OH}$ and/or unreduced $\mathrm{Ni}^{2+}$ [101].

\subsection{Active Phases}

Transition metal phosphides involving unsupported MoP and supported NixP, CoxP, WxP, MoxP, FexP, and RuxP metal phosphides have been reported as efficient catalysts for HDO [77].

These phosphides contain Brønsted and Lewis acid sites, which are active in the different reactions occurring during HDO processes. Thus, the transition metal (TM) develops a small positive charge $\left(\mathrm{M}^{\delta+}\right)$, which acts as Lewis acid site in reactions such as hydrogenation, hydrogenolysis, and demethylation [79]. Brønsted acid sites are related to the formation of PO-H that participates in producing active hydrogen species, as hydroxyl groups promote hydrogen spillover and stabilize these species $[75,102]$. In addition to this acid property, these compounds are also characterized by a metal function, enabling them to serve as a bifunctional catalyst [45].

However, as the acidity of metal phosphides is rather weak, and depending on the reactant molecule, additional acid groups might need to be incorporated into the support. For instance, the deoxygenation reaction mediated by the dehydration of alcohols is a rather slow process at low temperatures, being the rate-limiting step in the consecutive hydrogenation reaction of 
phenolic compounds. A simple and effective way to introduce acid sites on a solid substrate is to deposit active species on porous materials with strong acidity, such as protonated zeolites [101]. Therefore, in the case of alcohols, the reaction mechanism would most likely proceed through hydrogenation/dehydrogenation steps for silica-supported catalysts, while for zeolite HZSM-5, the reaction mechanism would be based on acid-base-catalyzed dehydration steps $[12,103]$. Researchers have proposed that oxygenated compounds and hydrogen are adsorbed on $\mathrm{M}^{\delta+}$ sites on silica-supported TMP. Then, $\mathrm{H}$ atoms react with adsorbed oxygenated compounds, producing the deoxygenated compound and water [75]. This last by-product deactivates the phosphide by partial oxidation [12], in the absence of a sufficient desorption and diffusion, resulting in the oxidation of the phosphide to phosphate or even to the metal oxide.

The ligand effect of P may enhance the oxidation resistance of the MP. Li et al. have compared the oxidation resistance of $\mathrm{Mo}^{\delta+}$ and $\mathrm{Ni}^{\delta+}$, and a higher oxidation resistance of $\mathrm{Ni}^{\delta+}$ sites was observed [75].

The activity of the different transition metals depends on the reactant type and reaction conditions, as well as on the transition metal nature, MP loading, M/P ratio, support type, and preparation method [104], which will be discussed below. Extensive research has been conducted on this topic during the last year. Table 2 summarizes the main published studies on the HDO of waste oil oxygenates (model compounds), with the exception of phenolic compounds (existing in bio-oil produced by the fast pyrolysis of crop residue biomass), which have been recently reviewed by Shafaghat et al. [105]. Table 3 compiles the main contributions to the HDO of waste oils using real feeds.

Here, some remarks on the use of MPs for the HDO of oil model compounds were compiled.

One of the first investigations of this topic indicates that $\mathrm{Ni}_{2} \mathrm{P}$ appears to be very active for HDO (as well as for HDS and HDN), but not for C-C cracking [8,14]. When the activity for HDO is compared among different MPs, the trend changes, depending mainly on the nature of MP and reactant. For instance, the trend identified for the HDO of 2-methyl tetrahydrofuran at $300{ }^{\circ} \mathrm{C}$ and $1 \mathrm{~atm}$ with silica-supported catalysts was $\mathrm{Ni}_{2} \mathrm{P}>\mathrm{WP}>\mathrm{MoP}>\mathrm{CoP}>\mathrm{FeP}$, but the trend for total conversion and the selectivity towards $\mathrm{HDO}$ products was $\mathrm{MoP}>\mathrm{WP}>\mathrm{Ni}_{2} \mathrm{P}>\mathrm{FeP}>\mathrm{CoP}$. In another study examining the HDO of guaiacol [81], the turnover frequency in terms on the number of active sites as titrated by CO chemisorption followed the order of $\mathrm{Ni}_{2} \mathrm{P}>\mathrm{Co}_{2} \mathrm{P}>\mathrm{Fe}_{2} \mathrm{P}, \mathrm{WP}$, and MoP.

Silica-supported $\mathrm{Ni}_{2} \mathrm{P}, \mathrm{MoP}$, and $\mathrm{NiMoP}$ catalysts were tested for the $\mathrm{HDO}$ of anisole. Among them, the $\mathrm{NiMoP} / \mathrm{SiO}_{2}$ catalyst with a larger $\mathrm{Ni} / \mathrm{Mo}$ ratio exhibited higher activity. In this phosphide, the $\mathrm{Ni}^{\delta+}$ and $\mathrm{Mo}^{\delta+}$ sites bearing small positive charges showed not only Lewis acid sites for demethylation, but also metal sites for hydrogenolysis and hydrogenation reactions. The higher activity of the $\mathrm{Ni}^{\delta+}$ site than the $\mathrm{Mo}^{\delta+}$ site was associated to the higher $d$ electron density in $\mathrm{Ni}_{2} \mathrm{P}$. The catalysts can be oxidized by the water product by forming the corresponding metal oxide and/or phosphate. The high stability of $\mathrm{Ni}_{2} \mathrm{P} / \mathrm{SiO}_{2}$ catalyst may be the result of the ligand effect of $\mathrm{P}$, which decreases the electron density of $\mathrm{Ni}$ and inhibits the formation of $\mathrm{Ni}-\mathrm{O}$ [75].

The optimum proportion of the active phase depends on the metal phosphide, support type, and reactant. For instance, Oyama et al. [15] studied the effect of Ni loading (from $6 \mathrm{wt} \%$ to $22 \mathrm{wt} \% \mathrm{Ni}_{2} \mathrm{P}$ ) prepared by a temperature-programmed reduction and found that the optimum proportion of $\mathrm{Ni}$ is approximately $18 \%$ (weight) for the HDS, HDN, and HDO of dibenzothiophene, quinolone, and benzofuran. For catalysts with Ni loading above the optimum, the crystallite size only increased slightly.

As stated above, the specific mechanism depends on the TMP and support nature. These reaction mechanisms have been well documented by Robinson et al. [106] in those works concerning the deoxygenation of pyrolysis oil components. These studies show the importance of catalyst bifunctionality, highlighting that catalysts require hydrogenation and $\mathrm{C}-\mathrm{O}$ scission sites to perform $\mathrm{HDO}$ at reasonable rates. Mechanistic studies for HDO of waste oils and fats to produce HVO-green diesel are scarce. Peroni et al. [107] studied the reaction mechanism of palmitic acid HDO over bulk 
transition metal phosphides (WP, MoP, and Ni2P) and reported that the activation energies varied from $57 \mathrm{~kJ} \mathrm{~mol}-1$ for MoP to $142 \mathrm{~kJ} \mathrm{~mol}-1$ for WP. Moreover, it is pointed out that the reduction of the fatty acid to the aldehyde proceeds through a Langmuir-Hinshelwood mechanism, where the rate-determining step is the addition of the second $\mathrm{H}$ to the hydrocarbon.

The reaction mechanism for the HDO of bio-oil and waste oil components can be also approached by theoretical calculations, by density functional theory (DFT), which can help to unravel the rate-determining steps for this process, which has been reviewed by Li et al. [108]. Recently, hydrodeoxygenation of phenol on bimetallic phosphide catalysts has been studied using both experimental and theoretical methods [109] to identify C-O bond cleavage pathways and product selectivities for HDO reactions on FeMoP, RuMoP, and NiMoP catalysts. It is established that FeMoP catalyst favors direct deoxygenation pathway because of a lower activation energy barrier for $\mathrm{C}-\mathrm{O}$ bond cleavage, whereas RuMoP and NiMoP catalysts promote ring hydrogenation first, followed by the cleavage of the $\mathrm{C}-\mathrm{O}$ bond.

\subsection{Influence of Metal-Phosphorus Ratio: Role of Phosphorous}

Phosphorous exerts an important role in the activity of MP for HDO reactions. First, P sites produce a ligand effect on the metal sites by altering the electron density of the metal cation, thus facilitating hydrogen dissociation. In addition, the MP may contain $\mathrm{P}-\mathrm{OH}$ groups that are moderately acid sites suitable to promote hydrogenation reactions $[15,45]$.

The influence of $\mathrm{M} / \mathrm{P}$ ratio was first investigated by Oyama et al. [15] using NiP catalysts supported on silica for HDS and HDN reactions. They showed that catalysts with excess P lost some of their $\mathrm{P}$ content in the course of the reduction reaction. The Ni/P ratio was found to exert a minimal effect in the HDS reactions, but it was more important on the HDN reactions. It was also observed that both the HDS activity and stability became affected profoundly by the phosphorus content, both reaching a maximum with an initial $\mathrm{Ni} / \mathrm{P}$ ratio of nearly $1 / 2$ (which reached an $\mathrm{Ni} / \mathrm{P}$ ratio of $2 / 1$ ). For lower $\mathrm{P}$ loading, some Ni metal and $\mathrm{Ni}_{12} \mathrm{P}_{5}$ phases were obtained, and at a higher $\mathrm{P}$ concentration, the $\mathrm{Ni}_{2} \mathrm{P}$ active phase was blocked by excess $\mathrm{P}$.

Once an initial M/P ratio is selected, the final M/P ratio depends on the reduction temperature (if the preparation method is the temperature-programmed reduction reaction) and the support type; the resulting $\mathrm{NiP}$ phase depends on both the $\mathrm{P} / \mathrm{M}$ molar ratio used during the synthesis procedure and the support applied [18]. One of the most active phases for HDO with different reactants is nickel phosphide, which is why the influence of the $M / P$ ratio has been extensively studied for NixPy-based catalysts.

In the case of an almost inert support such as $\mathrm{SiO}_{2}$, the $\mathrm{Ni}_{2} \mathrm{P}$ phase was obtained from a $\mathrm{P} / \mathrm{Ni}$ ratio greater than 0.8 ; for lower $\mathrm{P} / \mathrm{Ni}$ values, the presence of the $\mathrm{Ni}_{12} \mathrm{P}_{5}$ phase has also been detected [82,85,110]. For acidic supports, such as $\gamma-\mathrm{Al}_{2} \mathrm{O}_{3}$ [85,111], HZSM-22 [112], and HY [85], a large excess of $\mathrm{P}(\mathrm{P} / \mathrm{Ni}$ higher than 2$)$ was required to obtain the $\mathrm{Ni}_{2} \mathrm{P}$ phase. This finding is ascribed to a strong interaction of $\mathrm{P}$ at the support interface [113].

The most active and selective Ni-P stoichiometry for HDO depends on the support type and the specific reactant.

For silica-supported catalysts, $\mathrm{Ni}_{2} \mathrm{P}$ was more active than the $\mathrm{Ni}_{12} \mathrm{P}_{5}$ phase for the HDO of different reactants, such as dibenzofuran [110], methyl laurate [82], and methyl oleate [83]. Excess phosphorous and an $\mathrm{Ni} / \mathrm{P}$ molar ratio lower than the stoichiometric ratio must be used to obtain this stoichiometry $[82,114]$. For the HDO of methyl palmitate, the reactivity increased along with a decrease in the Ni/P ratio (higher content of POx groups). This finding has been explained by the increase of the rate of methyl palmitate conversion as accelerated by the acid-catalyzed hydrolysis [87].

For palmitic acid HDO with catalysts based on nickel phosphide supported on activated carbon, a synergy between $\mathrm{Ni}_{2} \mathrm{P}$ and $\mathrm{Ni}_{12} \mathrm{P}_{5}$ has been reported [115]. 
$\mathrm{Ni}_{12} \mathrm{P}_{5}$ has been found to be more active than $\mathrm{Ni}_{2} \mathrm{P}$-based catalyst for the HDO of guaiacol (silica-supported catalyst) [116], methyl laurate (alumina-supported catalyst) [111], and palmitic acid (HZSM-22-supported catalyst) [112].

The influence of the M/P ratio has also been studied for the HDO of a real feed such as wood-derived pyrolysis oil. The properties of the upgraded bio-oils were substantially altered by the phosphorus content in both $\mathrm{Ni}$ and Co catalysts (supported on activated carbon). The best performance was typically achieved with a metal/P molar ratio of approximately $3 / 2$ [117]. A further increase in $\mathrm{P} / \mathrm{M}$ produced increases in both the $\mathrm{O} / \mathrm{C}$ and $\mathrm{H} / \mathrm{C}$ ratios, suggesting that $\mathrm{HDO}$ decreases although hydrogenation activity increases. A similar optimized ratio was identified for a series of nickel phosphide catalysts supported on activated carbon for the HDO of waste cooking oil, and smaller $\mathrm{Ni}_{2} \mathrm{P}$ crystallite sizes were found at lower $\mathrm{Ni} / \mathrm{P}$ ratios [118].

Recently, the $\mathrm{P} /$ metal ratio for a series of nickel phosphide catalysts supported on $\mathrm{ZrO}_{2}$ has been optimized. The $\mathrm{P} / \mathrm{Ni}$ ratio that produced the best catalytic performance for the HDO of $\mathrm{m}$-cresol is equal to 3. This finding is attributed to the presence of the pure $\mathrm{Ni}_{2} \mathrm{P}$ phase, about five times more active than the $\mathrm{Ni}_{12} \mathrm{P}_{5}$ phase [113].

\subsection{Support Types and Influence on Reactivity}

Both the nature of the active phase and its dispersion are strongly influenced by the type of the support and by its acidity [18]. Thus, the use of supported TMPs might increase the dispersion of the active phase, which may have an economic benefit and an effect on reactivity, as HDO is a structure-sensitive reaction that is influenced by the crystallite size and depends on the nature and properties of the support. As shown in the study by Oyama et al. [45], two types of Ni sites [tetrahedral $\mathrm{Ni}(1)$ sites and square pyramidal $\mathrm{Ni}(2)$ sites] are located on $\mathrm{Ni}_{2} \mathrm{P}$ crystallites [28]. Moreover, the proportion of $\mathrm{Ni}(2)$ sites increases with the decreasing crystallite size, and these sites are responsible for hydrogenation [29] as a consequence of the stronger interaction between the $\mathrm{Ni}(2)$ sites and the $\mathrm{P}$ atoms [4].

Some properties of the support that potentially influence the reactivity of the supported TMPs phosphides are acidity, reducibility, and 3D-ordered pore geometry.

One of the most frequently used supports for TMPs in HDO reactions is silica, because it is an inert (or neutral) support that enables researchers to more specifically examine the influence of the nature of supported TMPs on reactivity, and because it is commercialized as a relatively high surface area material that favors a higher dispersion of the active phases.

The surface polarity of silica can be tuned up to increase the activity and stability against the oxidation of TMP by water. Moreover, the polarity of the support surface has been modulated by copolymerizing tetraethyl orthosilicate (TEOS) with different types and amounts of organosilanes [119]. As catalyst performance and support surface polarity exhibited some correlation, it was inferred that the affinity of the support for polar substances must be decreased below a threshold value-this factor is critical if deactivation of the catalyst by water product has to be minimized.

Another possible support for MPs is alumina $\left(\mathrm{Al}_{2} \mathrm{O}_{3}\right)$, which displays high stability and moderate acidity. This support may lead to higher catalytic activity by enhancing the dehydration reaction in HDO. Porous alumina, silica-alumina, proton-type zeolites, and Al-doped ordered mesostructured silica supports, with moderate or strong surface acidity, are often used in acid-catalyzed dehydrations. Additionally, contrary to silica-based catalysts, acid sites are needed for the formation of nonlinear hydrocarbons and n-paraffins [120]. This approach would improve the quality of the synthesized fuel (cloud point, cetane number, etc.). Notably, the preparation method based on the temperature-programmed reduction of phosphite species is a potential problem when the support contains $\mathrm{Al}$ species, as the reaction of $\mathrm{Al}$ species with $\mathrm{P}$ species makes it difficult to control the metal/P ratio [101].

As mentioned above, the use of alumina as a support favors coke formation because of its high intrinsic acidity, which rapidly deactivates the catalyst. However, this property could be optimized by 
doping the catalyst with basic elements, such as $\mathrm{K}^{+}$, producing a deactivation of dehydration active sites by the replacement of $\mathrm{H}^{+}$in the Brønsted acid sites of the support with $\mathrm{K}^{+}$[105].

The effects of the support employing $\mathrm{SiO}_{2}$ and gamma- $\mathrm{Al}_{2} \mathrm{O}_{3}$ on surface and catalytic properties of nickel phosphide catalysts have been investigated. A comparison of $\mathrm{Ni}_{2} \mathrm{P} / \mathrm{SiO}_{2}$ and $\mathrm{Ni}_{2} \mathrm{P} / \mathrm{Al}_{2} \mathrm{O}_{3}$ catalysts revealed the higher catalytic efficiency of alumina-supported $\mathrm{Ni}_{2} \mathrm{P}$ in methyl palmitate HDO. The results are explained by the cooperation of $\mathrm{Ni}_{2} \mathrm{P}$ and acid sites on the surface of alumina that enhances the activity of alumina-supported $\mathrm{Ni}_{2} \mathrm{P}$ by enhancing the rate of hydrolysis [121].

A strong effect of the support type $\left(\mathrm{SiO}_{2}, \mathrm{CeO}_{2}, \mathrm{TiO}_{2}\right.$, and SAPO-11) on the HDO of methyl laurate with $\mathrm{Ni}_{2} \mathrm{P}$ as initial active phase has been observed [85]. The nature of the nickel phosphide evolves differently depending on the support type, yielding different Ni-P stoichiometries. The catalyst with a higher conversion rate and selectivity towards $C_{11}$ and $C_{12}$ hydrocarbons was the one supported on silica. However, this catalyst presented the lowest rate as a consequence of the reduced support effect. Thus, the Brønsted acid sites and oxygen vacancies on the support (which are present in reducible supports, such as ceria and titania) result in a promotion of the conversion of methyl laurate.

The use of ordered mesoporous materials with a narrow pore size distribution for the support, which are appropriate for the average size of organic molecules present in waste oils, might increase the active phase dispersion and prevent the sintering effect during the incorporation of the active phase and during the reaction. In addition, the large pore size of mesoporous silica favors diffusion of reactant molecules.

Mesostructured silica supports, such as SBA-15 and MCM-41, appeared to be of great importance for HDO reactions because these ordered mesoporous substrates, with high surface/volume ratio, improve the dispersion of metal phosphides and further enhance their HDO performance [122].

As these mesoporous silica SBA-15 and MCM-41 also show good stability, they are being considered suitable supports for HDO processes.

Yang et al. [86] have studied the deoxygenation of methyl laurate to hydrocarbons on $\mathrm{Ni}_{2} \mathrm{P} / \mathrm{SiO}_{2}$, $\mathrm{Ni}_{2} \mathrm{P} / \mathrm{MCM}-41$, and $\mathrm{Ni}_{2} \mathrm{P} / \mathrm{SBA}-15$ catalysts. They reported that both the conversion and selectivity towards $\mathrm{C}_{11}$ and $\mathrm{C}_{12}$ hydrocarbons, depending on the support, follow the trend $\mathrm{SiO}_{2}>\mathrm{SBA}-15>$ MCM-41. However, the intrinsic activity (turnover frequency, or molecules reacting per active site per time) increased with the $\mathrm{Ni}_{2} \mathrm{P}$ crystallite size (SBA-15 $\left.>\mathrm{SiO}_{2}>\mathrm{MCM}-41\right)$, and was associated with the stronger interaction between $\mathrm{Ni}$ and $\mathrm{P}$ in smaller $\mathrm{Ni}_{2} \mathrm{P}$ crystallites. Thus, the decarbonylation pathway is favored when the $\mathrm{Ni}$ sites have fewer interactions with $\mathrm{P}$.

Acidity has been optimized by doping the aforementioned ordered supports with a certain proportion of aluminum. This property has been studied in some TMSs $\left(\mathrm{Ni}_{2} \mathrm{P}, \mathrm{Co}_{2} \mathrm{P}\right.$, and $\left.\mathrm{MoP}\right)$ prepared through the temperature-programmed reduction of the corresponding phosphate precursors loaded over mesostructured Al-SBA-15, mesoporous $\gamma-\mathrm{Al}_{2} \mathrm{O}_{3}$, and ordered mesoporous carbon and tested in phenol hydrogenation [30]. Although the phenol conversion rate increases with the support acidity, the HDO efficiency depends on the TMP and support types, as $\mathrm{Ni}_{2} \mathrm{P} / \mathrm{Al}-\mathrm{SBA}-15$ was the only catalyst with a high HDO efficiency, resulting in almost complete phenol conversion and cyclohexane selectivity greater than $90 \%$. This behavior is explained in terms of the synergetic effect between the $\mathrm{Ni}^{\alpha+}(0<\alpha<1)$ species, originated by an electron transfer from $\mathrm{Ni}$ to $\mathrm{P}$, and the acidic sites present in the catalyst. Another important conclusion of this study is that the activity of the metal phosphide is reduced on an alumina support, and only metallic nickel and cobalt were detected, which likely favor the formation of carbon.

Benzofuran $\mathrm{HDO}$ has been studied with $\mathrm{Ni}_{2} \mathrm{P} / \mathrm{Al}-\mathrm{SBA}-15$ catalysts. The incorporation of $\mathrm{Al}$ into the SBA-15 support not only increases the acid strength, but also promotes the formation of highly dispersed $\mathrm{Ni}_{2} \mathrm{P}$ particles on the surface. $\mathrm{Al}$ also contributes to suppress the enrichment of $\mathrm{P}$, and consequently increases $\mathrm{Ni}$ dispersion [123].

Zeolite HZSM-5 supports have also been successfully used to prepare MP catalysts for HDO through hydrogenation and dehydration mechanisms proceeding over MP and acid sites of HZSM-5, respectively. For instance, $\mathrm{Ni}_{2} \mathrm{P} / \mathrm{H}-\mathrm{ZSM}-5$ and $\mathrm{Ni}_{2} \mathrm{P} / \mathrm{SiO}_{2}$ catalysts were compared for m-cresol HDO 
to methylcyclohexane. The higher activity of the zeolite-supported catalyst was ascribed to the synergy between the metal phosphide (which introduces new Lewis and Brønsted acid sites) and the solid acid support, with rates for the $\mathrm{HDO}$ of $\mathrm{m}$-cresol that depend on $\mathrm{Ni}_{2} \mathrm{P}$ dispersion; this indicates that reaction is sensitive to the structure, with an optimum activity observed for a particle size of approximately $4 \mathrm{~nm}$ [124]. A similar bifunctional catalyst $\left(\mathrm{Ni}_{3} \mathrm{P} / \mathrm{HZSM}-5\right)$ with $\mathrm{Ni}_{3} \mathrm{P}$ as the hydrogenation site and HZSM- 5 as dehydration site was used for the HDO of phenol, catechol, and o-cresol, and showed excellent performance. The strong acidity function of HZSM- 5 also facilitated the isomerization of cycloalkanes at high temperatures [101].

\subsection{Promoters}

Promoters alter the activity and selectivity by influencing different catalytic properties, such as the physical (such as textural and morphological properties) and chemical properties (nature of active phases).

Some noble metals, such as $\mathrm{Ru}, \mathrm{Rh}$, and $\mathrm{Ir}$, function as chemical promoters in transition metal phosphides, producing a synergistic effect by improving the hydrogenating capacity of the active phase, mainly at low temperatures. Thus, nickel in $\mathrm{Ni}_{2} \mathrm{P}$ has been partially substituted with $\mathrm{Ru}, \mathrm{Rh}$, and $\mathrm{Ir}$, and the activity in the HDO of dibenzofuran was evaluated. $\mathrm{H}_{2}$ activation is improved in the presence of these noble metals, and $\mathrm{Ni}_{1.8} \mathrm{Rh}_{0.2} \mathrm{P}$ was the most active composition. The presence of these noble metals in the phosphide prevents $\mathrm{Ni}$ oxidation and increases the number of surface $\mathrm{P}-\mathrm{OH}$ groups, which provide $\mathrm{H}$ species to react with the activated $\mathrm{O}$ molecules [125]. A small addition of $\mathrm{Ru}(0.5 \% \mathrm{Ru})$ to $\mathrm{Ni}_{3} \mathrm{P}_{2}$ and $\mathrm{Co}_{3} \mathrm{P}_{2}$ decreased the molecular weight of the upgraded bio-oil, yielding high-quality products similar to those obtained with an expensive commercial $5 \mathrm{wt} \% \mathrm{Ru} / \mathrm{C}$ catalyst [117]. The presence of this small amount of Ru increased the hydrogenation activity (giving a higher $\mathrm{H} / \mathrm{C}$ ratio for the resulting products), but did not substantially affect the catalysts' $\mathrm{HDO}$ activity.

In addition to using a support with a high surface area, another approach to increase the dispersion of the active sties is to use a proper additive during catalyst preparation. An improvement in hydrodeoxygenation stability has been achieved using a physical $\mathrm{O}$ structural promoter in a catalyst based on nickel phosphide supported on $\alpha-\mathrm{Al}_{2} \mathrm{O}_{3}\left(\mathrm{Ni}_{2} \mathrm{P}-\mathrm{Pd} / \alpha-\mathrm{Al}_{2} \mathrm{O}_{3}\right)$. In this case, the catalyst has been modified with $\mathrm{SiO}_{2}$ (a spacer), achieving a promising catalyst for the HDO of soybean oil. The addition of $\mathrm{SiO}_{2}$ made the reaction between $\mathrm{H}_{2} \mathrm{O}$ and $\mathrm{Ni}_{2} \mathrm{P}$ slower. This reaction is the main reason for $\mathrm{P}$ loss and consequent deactivation, as the subsequent formation of metallic nickel favors carbon formation [126].

Carbon has also been used as a structural promoter in MoP, which was prepared using a citric acid method combined with a final temperature-programmed reduction. A decrease in the extent of MoP aggregation was observed in this reaction [127]. In another study, carbon (with citric acid as precursor) has also been successfully used as a structural promoter in MoP catalysts for the HDO of 4-methylphenol. The residual carbon had the role of structural promoter of the calcined samples, restraining the agglomeration of the $\mathrm{MoP}$ crystallites during reduction [128]. In reactions using MoP prepared with citric acid, the direct hydrogenolysis pathway prevailed over the hydrogenation pathway; however, in reactions using MoP prepared without citric acid, the rates of both pathways were nearly the same [105]. 
Table 2. Some literature studies on HDO of hydrotreated vegetable oils (HVO) (model compounds).

\begin{tabular}{|c|c|c|c|c|c|c|c|}
\hline Reactant & Catalysts & $\begin{array}{l}\text { Preparation } \\
\text { Method }\end{array}$ & Reactor & $\operatorname{Temp}\left({ }^{\circ} \mathrm{C}\right)$ & P (bar) & Conversion/Select. & Ref. \\
\hline \multicolumn{8}{|c|}{ Alkyl esters } \\
\hline $\begin{array}{l}\text { Methyl } \\
\text { laurate }\end{array}$ & $\begin{array}{c}\mathrm{Ni}_{2} \mathrm{P} / \mathrm{SiO}_{2} \\
\mathrm{Ni}_{2} \mathrm{P} / \mathrm{MCM}-41 \\
\mathrm{Ni}_{2} \mathrm{P} / \mathrm{SBA}-15\end{array}$ & phosphate & flow & $300-340$ & 20 & $\begin{array}{c}\text { Conv }>97 \% \text { and select to } \\
\quad C_{11}+C_{12}>99 \%\end{array}$ & [86] \\
\hline $\begin{array}{l}\text { Methyl } \\
\text { laurate }\end{array}$ & $\begin{array}{c}\mathrm{Ni} \text { phosphide } \\
\text { (initial } \mathrm{Ni} / \mathrm{P}= \\
1) / \mathrm{SiO}_{2}, \mathrm{CeO}_{2} \\
\mathrm{TiO}_{2} \text {, and } \mathrm{SAPO}-11 \text {, }\end{array}$ & phosphate & flow & $300-340$ & 20 & $\begin{array}{l}\text { Conv and select to } \mathrm{C}_{11}+\mathrm{C}_{12} \\
\text { alkanes close to } 100 \% \text { for } \\
\mathrm{Ni}_{2} \mathrm{P} / \mathrm{SiO}_{2}\left(340^{\circ} \mathrm{C}\right)\end{array}$ & [85] \\
\hline $\begin{array}{l}\text { Methyl } \\
\text { oleate }\end{array}$ & NixPy/SBA-15 & phosphate & flow & $250-340$ & $3-40$ & $\begin{array}{l}\text { For } \mathrm{Ni} / \mathrm{P}=1,80 \% \text { Conv, } \\
\left(30 \mathrm{bar}, 290^{\circ} \mathrm{C}\right)\end{array}$ & [83] \\
\hline $\begin{array}{l}\text { Methyl } \\
\text { oleate } \\
(70 \%)\end{array}$ & $\begin{array}{c}(\mathrm{Fe}, \mathrm{Co}, \mathrm{Ni} \text {, and } \mathrm{Mo}) \\
\text { phosphides }(\mathrm{M} / \mathrm{P}= \\
1, \text { initial }) \text { dispersed } \\
\text { on SBA-15 }\end{array}$ & phosphate & flow & 250 & $3-40$ & $\begin{array}{l}\text { Higher conversion for } \\
\mathrm{Ni}_{2} \mathrm{P} / \mathrm{SBA}-15 \\
\text { HDO selectivity with } \\
\mathrm{MoP} / \mathrm{SBA}-15>90 \%\end{array}$ & [129] \\
\hline $\begin{array}{l}\text { Methyl } \\
\text { palmitate }\end{array}$ & $\begin{array}{c}\mathrm{Ni}_{2} \mathrm{P} / \mathrm{SiO}_{2} \text { catalyst, } \\
\text { and in mixture with } \\
\text { inert }\left(\mathrm{SiC} \text { or } \mathrm{SiO}_{2}\right) \\
\text { or acidic }\left(\gamma-\mathrm{Al}_{2} \mathrm{O}_{3}\right)\end{array}$ & phosphate & flow & $270-330$ & 30 & $\begin{array}{l}\text { Conv }=100 \%\left(310^{\circ} \mathrm{C}\right) \\
\mathrm{Ni}_{2} \mathrm{P} / \mathrm{SiO}_{2}\left(\gamma-\mathrm{Al}_{2} \mathrm{O}_{3}\right)\end{array}$ & [130] \\
\hline $\begin{array}{l}\text { Methyl } \\
\text { palmitate }\end{array}$ & $\mathrm{Ni}_{2} \mathrm{P} / \mathrm{SiO}_{2}$ & phosphate & flow & 290 & 30 & $\begin{array}{c}\text { Catalyst reduced at } 600{ }^{\circ} \mathrm{C} \text {, } \\
6 \text { h: } 15 \mathrm{~mol} \mathrm{MP} / \mathrm{h} \cdot \mathrm{mol} \mathrm{Ni} \\
\text { Select. } \mathrm{C}_{16} \sim 62 \%\end{array}$ & [131] \\
\hline $\begin{array}{l}\text { Methyl } \\
\text { palmitate }\end{array}$ & $\begin{array}{c}\mathrm{NiP} / \text { silica } \\
(\mathrm{Ni} / \mathrm{P} \text { molar ratio } \\
2 / 1,1 / 1 \text { and } 1 / 2)\end{array}$ & phosphate & flow & 290 & 30 & $\begin{array}{l}\mathrm{Ni}_{2} \mathrm{P}: \text { Conv close to } 100 \% \text { at } \\
\text { the beginning (fast } \\
\text { deactivation in } 6 \mathrm{~h} \text { ) }\end{array}$ & [87] \\
\hline $\begin{array}{c}\text { Methyl } \\
\text { palmitate }\end{array}$ & $\begin{array}{c}\mathrm{Ni}_{2} \mathrm{P} / \gamma-\mathrm{Al}_{2} \mathrm{O}_{3} \\
\mathrm{Ni}_{2} \mathrm{P} / \mathrm{SiO}_{2}\end{array}$ & $\begin{array}{l}\text { phosphate } \\
\text { and } \\
\text { phosphite }\end{array}$ & flow & $250-330$ & 30 & $\begin{array}{l}\text { Conv }=95 \%\left(320^{\circ} \mathrm{C}\right) \text { with } \\
\mathrm{Ni}_{2} \mathrm{P} / \mathrm{Al}_{2} \mathrm{O}_{3} \text { (phosphate) }\end{array}$ & [121] \\
\hline \multicolumn{8}{|c|}{ Carboxylic acids } \\
\hline $\begin{array}{l}\text { Palmitic } \\
\text { acid }\end{array}$ & $\begin{array}{c}\mathrm{Ni}_{2} \mathrm{P} \text { and } \mathrm{MoP} \text { bulk } \\
\text { and supported on } \\
\gamma-\mathrm{Al}_{2} \mathrm{O}_{3}\end{array}$ & phosphate & flow & 180-300 & 40 & $\begin{array}{l}\text { Conversion: } 80 \% \text { and } 60 \% \text { for } \\
\text { supported } \mathrm{Ni}_{2} \mathrm{P} \text { and } \mathrm{MoP} \text {, } \\
\text { respectively }\left(300{ }^{\circ} \mathrm{C}\right)\end{array}$ & [132] \\
\hline
\end{tabular}

Table 3. Some literature studies on HDO of hydrotreated vegetable oils, HVO (real feeds).

\begin{tabular}{|c|c|c|c|c|c|c|c|}
\hline Feed & Catalyst & $\begin{array}{l}\text { Preparation } \\
\text { Method }\end{array}$ & Reactor & $\operatorname{Temp}\left({ }^{\circ} \mathrm{C}\right)$ & $\mathbf{P}$ (bar) & Conv/Select. & Ref. \\
\hline Castor oil & $\mathrm{Ni}_{2} \mathrm{P} / \mathrm{SAPO}-11$ & phosphite & Flow & 300 & 30 & $\begin{array}{c}\text { Conv }=99 \% \\
\text { yield to } C_{16}-C_{19}= \\
92.3 \%\end{array}$ & [133] \\
\hline (Spent) coffee oil & $\mathrm{NiP} /$ alumina & phosphate & Batch & $375-425$ & $20-40$ & $\begin{array}{c}77.4 \% \text { conv. } \\
\text { Yield to gasoline }= \\
31.2 \% \text {, Yield to } \\
\text { diesel } 33.8 \%\left(400{ }^{\circ} \mathrm{C}\right. \\
\text { and } 40 \text { bar })\end{array}$ & [134] \\
\hline $\begin{array}{l}\text { Fast pyrolysis oil } \\
\text { (Commercial } \\
\text { Alcohol Inc. } \\
\text { Hardwood } \\
\text { sawdust) }\end{array}$ & $\begin{array}{c}\mathrm{Ni} \text { or Co } \\
\text { phosphide/activated } \\
\text { carbon }\end{array}$ & phosphate & Batch & 300 & 50 & $\begin{array}{l}\text { Greater yields for } \\
\qquad \mathrm{M} / \mathrm{P}=3 / 2\end{array}$ & [117] \\
\hline Soybean oil & $\mathrm{Ni}_{2} \mathrm{P}-\mathrm{Pd}-\mathrm{SiO}_{2} / \alpha-\mathrm{Al}_{2} \mathrm{O}_{3}$ & $\begin{array}{l}\text { Hydrothermal } \\
\text { + phosphate } \\
\text { method }\end{array}$ & Flow & 340 & & Nearly $100 \%$ conv & [126] \\
\hline Soybean oil & $\begin{array}{c}\mathrm{Ni}_{2} \mathrm{P} / \mathrm{SiO}_{2} \text { and } \\
\mathrm{Ni}_{2} \mathrm{P} / \mathrm{HY}\end{array}$ & $\begin{array}{l}\text { Phosphate } \\
\text { method }\end{array}$ & Flow & $340-370$ & 30 & $\begin{array}{c}\text { Organic liquid yield, } \\
\text { wt } \%>82 \%\end{array}$ & [135] \\
\hline
\end{tabular}

\section{General Conclusions and Perspectives}

Processes that produce biodiesel from biomass or plant oils are an alternative to petroleum-based fuels. One of most interesting options is the hydrotreatment of vegetable oils or animal fats, usually known as renewable diesel fuels. Hydrotreatment of vegetable oils or animal fats is one of the more attractive processes in the production of biofuels in terms of carbon mass balance (approximately 95\%) [3]. The quality of the hydrotreated vegetable oils (HVO) is clearly higher than that of ester-type 
biodiesel fuels. HVOs do not produce increases in NOx emission, the formation of deposits is minimized, they have a long stability, they have high compatibility with engine oil, and they have good cold properties. HVOs are straight chain paraffinic hydrocarbons without aromatics, oxygen, and sulfur, and with high cetane numbers [4]. TMPs have higher resistance to water presence with respect to other active phases like sulfides, carbides, or nitrides. Supported sulfides, especially Ni and/or Mo, are quite efficient active catalysts in HDO, but in the treatment of biomass sources with low sulfur, it is necessary for the feed of sulfur containing compounds to retain the high catalytic activity. However, this practice has serious drawbacks from environmental and operational perspectives; in contrast, TMPs do not need any additive feed. TMPs beat noble metal catalysts because catalysts based on TMPs are made with more abundant and less expensive elements than noble metals. This characteristics make TMPs an excellent active phase in HDO with clear advantages with respect to other catalysts employed at present.

The main active phases for these metal phosphides during $\mathrm{HVO}$ are $\mathrm{M}^{\delta+}$ (where $\mathrm{M}$ stands for a transition metal with a small positive charge) and Brønsted sites, which act as Lewis acid sites in reactions such as hydrogenation, hydrogenolysis, and demethylation. Brønsted acid sites are related to the formation of $\mathrm{PO}-\mathrm{H}$, which participates in producing active hydrogen species, as hydroxyl groups promote hydrogen spillover and stabilize these species [75,102]. In addition to this acid property, these compounds are also characterized by a metal function, enabling them to serve as a bifunctional catalyst [45].

Despite the published studies, there are still some interesting ways to improve the catalytic performance of TMPs as catalysts in the hydrotreatment of vegetables oils. Deeper studies on innovative methods of TMPs' synthesis are necessary, because the behavior of the traditional gas phase preparation can be improved with other methodologies, for instance, liquid phase synthesis. Additionally, there are only a few studies about the use of bimetallic phosphides or promoted TMP systems- the use of this kind of catalytic systems would improve the activity behavior, because the catalytic performance can be tuned in function of the composition of bimetallic TMPs. Taking into account that the reaction is a three-phase (gas-liquid-catalyst) reaction and the highly exothermic character of the reaction, there are windows for the improvement of the reaction system. On the basis of these assumptions, it is necessary to integrate the design of the mass transfer, reaction (catalysts), and heat transfer. At this point, microstructured reactors can be an interesting solution, where the characteristics of the microstructured reactor favor the mass and heat transfer. Then, the catalytic behavior can be improved when the catalyst design is closely integrated with the reactor design, taking into consideration the reaction mechanism, catalytic activity, and catalyst life time (and exchangeability).

Author Contributions: All authors have contributed equally in writing the original draft and reviewing and editing the manuscript.

Funding: This research was funded by Agencia Estatal de Investigación (Spain) grant number ENE2016-74889-C4-3-R and the APC was funded by the same grant.

Conflicts of Interest: The authors declare no conflicts of interest.

\section{References}

1. DIRECTIVE (EU) 2018/2001 OF THE EUROPEAN PARLIAMENT AND OF THE COUNCIL of 11 December 2018 on the Promotion of the Use of Energy from Renewable Sources (recast), page L 328/83. Available online: https: / / eur-lex.europa.eu/legal-content/EN/TXT/PDF / ?uri=CELEX:32018L2001\&from=EN (accessed on 28 February 2019).

2. Alleman, T.L.; McCormick, R.L.; Christensen, E.D.; Fioroni, G.; Moriarty, K.; Yanowitz, J. Biodiesel Handling and Use Guidelines, 5th ed.; DOE/GO-102016-4875; Clean Cities Publications; U.S. Department of Energy: Washington, DC, USA, 2016. 
3. Hilbers, T.J.; Sprakel, L.M.J.; van den Enk, L.B.J.; Zaalberg, B.; van den Berg, H.; van der Ham, L.G.J. Green Diesel from Hydrotreated Vegetable Oil Process Design Study. Chem. Eng. Technol. 2015, 38, 651-657. [CrossRef]

4. Hannu Aatola, M.L.; Sarjovaara, T.; Mikkonen, S. Hydrotreated Vegetable Oil (HVO) as a Renewable Diesel Fuel: Trade-off between NOx, Particulate Emission, and Fuel Consumption of a Heavy Duty Engine; SAE International: Warrendale, PA, USA, 2008.

5. Czernik, S.; Bridgwater, A.V. Overview of applications of biomass fast pyrolysis oil. Energy Fuels 2004, 18, 590-598. [CrossRef]

6. Venderbosch, R.H.; Prins, W. Fast pyrolysis technology development. Biofuels Bioprod. Biorefin. 2010, 4, 178-208. [CrossRef]

7. Wang, Y.X.; He, T.; Liu, K.T.; Wu, J.H.; Fang, Y.M. From biomass to advanced bio-fuel by catalytic pyrolysis/hydro-processing: Hydrodeoxygenation of bio-oil derived from biomass catalytic pyrolysis. Bioresour. Technol. 2012, 108, 280-284. [CrossRef]

8. Zhang, J.W.; Matsubara, K.; Yun, G.N.; Zheng, H.; Takagaki, A.; Kikuchi, R.; Oyama, S.T. Comparison of phosphide catalysts prepared by temperature-programmed reduction and liquid-phase methods in the hydrodeoxygenation of 2-methylfuran. Appl. Catal. A-Gen. 2017, 548, 39-46. [CrossRef]

9. Resasco, D.E. What Should We Demand from the Catalysts Responsible for Upgrading Biomass Pyrolysis Oil? J. Phys. Chem. Lett 2011, 2, 2294-2295. [CrossRef]

10. Furimsky, E. Catalytic hydrodeoxygenation. Appl. Catal. A-Gen. 2000, 199, 147-190. [CrossRef]

11. Arun, N.; Sharma, R.V.; Dalai, A.K. Green diesel synthesis by hydrodeoxygenation of bio-based feedstocks: Strategies for catalyst design and development. Renew. Sustain. Energy Rev. 2015, 48, 240-255. [CrossRef]

12. Carenco, S.; Portehault, D.; Boissiere, C.; Mezailles, N.; Sanchez, C. Nanoscaled Metal Borides and Phosphides: Recent Developments and Perspectives. Chem. Rev. 2013, 113, 7981-8065. [CrossRef]

13. Ruddy, D.A.; Schaidle, J.A.; Ferrell, J.R.; Wang, J.; Moens, L.; Hensley, J.E. Recent advances in heterogeneous catalysts for bio-oil upgrading via "ex situ catalytic fast pyrolysis": Catalyst development through the study of model compounds. Green Chem. 2014, 16, 454-490. [CrossRef]

14. Oyama, S.T.; Wang, X.; Lee, Y.K.; Chun, W.J. Active phase of $\mathrm{Ni}_{2} \mathrm{P} / \mathrm{SiO}_{2}$ in hydroprocessing reactions. J. Catal. 2004, 221, 263-273. [CrossRef]

15. Oyama, S.T.; Wang, X.; Lee, Y.K.; Bando, K.; Requejo, F.G. Effect of phosphorus content in nickel phosphide catalysts studied by XAFS and other techniques. J. Catal. 2002, 210, 207-217. [CrossRef]

16. Stinner, C.; Prins, R.; Weber, T. Binary and ternary transition-metal phosphides as HDN catalysts. J. Catal. 2001, 202, 187-194. [CrossRef]

17. Alexander, A.M.; Hargreaves, J.S. Alternative catalytic materials: Carbides, nitrides, phosphides and amorphous boron alloys. Chem. Soc. Rev. 2010, 39, 4388-4401. [CrossRef]

18. Prins, R.; Bussell, M.E. Metal Phosphides: Preparation, Characterization and Catalytic Reactivity. Catal. Lett. 2012, 142, 1413-1436. [CrossRef]

19. Shi, Y.; Zhang, B. Recent advances in transition metal phosphide nanomaterials: Synthesis and applications in hydrogen evolution reaction. Chem. Soc. Rev. 2016, 45, 1529-1541. [CrossRef] [PubMed]

20. Pei, Y.; Cheng, Y.; Chen, J.; Smith, W.; Dong, P.; Ajayan, P.M.; Ye, M.; Shen, J. Recent developments of transition metal phosphides as catalysts in the energy conversion field. J. Mater. Chem. A 2018, 6, 23220-23243. [CrossRef]

21. Oyama, S.T.; Gott, T.; Zhao, H.; Lee, Y.-K. Transition metal phosphide hydroprocessing catalysts: A review. Catal. Today 2009, 143, 94-107. [CrossRef]

22. Oyama, S.T. Novel catalysts for advanced hydroprocessing: Transition metal phosphides. J. Catal. 2003, 216, 343-352. [CrossRef]

23. Pöttgen, R.; Hönle, W.; von Schnering, H.G. Phosphides: Solid-State Chemistry. Encycl. Inorga. Bioinorg. Chem. 2011. [CrossRef]

24. Aronsson, B.; Lundstrom, T.; Rundqvist, S. Borides, Silicides and Phosphides: A Critical Review of Their Preparation, Properties and Crystal Chemistry; Wiley: Methuen, MA, USA; New York, NY, USA, 1965.

25. Habas, S.E.; Baddour, F.G.; Ruddy, D.A.; Nash, C.P.; Wang, J.; Pan, M.; Hensley, J.E.; Schaidle, J.A. A Facile Molecular Precursor Route to Metal Phosphide Nanoparticles and Their Evaluation as Hydrodeoxygenation Catalysts. Chem. Mater. 2015, 27, 7580-7592. [CrossRef] 
26. Roberts, E.J.; Habas, S.E.; Wang, L.; Ruddy, D.A.; White, E.A.; Baddour, F.G.; Griffin, M.B.; Schaidle, J.A.; Malmstadt, N.; Brutchey, R.L. High-Throughput Continuous Flow Synthesis of Nickel Nanoparticles for the Catalytic Hydrodeoxygenation of Guaiacol. ACS Sustain. Chem. Eng. 2017, 5, 632-639. [CrossRef]

27. Cecilia, J.A.; Infantes-Molina, A.; Rodríguez-Castellón, E.; Jiménez-López, A. A novel method for preparing an active nickel phosphide catalyst for HDS of dibenzothiophene. J. Catal. 2009, 263, 4-15. [CrossRef]

28. Clark, P.; Li, W.; Oyama, S.T. Synthesis and activity of a new catalyst for hydroprocessing: Tungsten phosphide. J. Catal. 2001, 200, 140-147. [CrossRef]

29. Bui, P.; Cecilia, J.A.; Oyama, S.T.; Takagaki, A.; Infantes-Molina, A.; Zhao, H.; Li, D.; Rodríguez-Castellón, E.; Jiménez López, A. Studies of the synthesis of transition metal phosphides and their activity in the hydrodeoxygenation of a biofuel model compound. J. Catal. 2012, 294, 184-198. [CrossRef]

30. Berenguer, A.; Sankaranarayanan, T.M.; Gomez, G.; Moreno, I.; Coronado, J.M.; Pizarro, P.; Serrano, D.P. Evaluation of transition metal phosphides supported on ordered mesoporous materials as catalysts for phenol hydrodeoxygenation. Green Chem. 2016, 18, 1938-1951. [CrossRef]

31. Qian, X.F.; Zhang, X.M.; Wang, C.; Wang, W.Z.; Qian, Y.T. A New Way to Prepare Nanocrystalline Dinickel Phosphide. Mater. Res. Bull. 1998, 33, 669-672. [CrossRef]

32. Qian, X.F.; Xie, Y.; Qian, Y.T.; Zhang, X.M.; Wang, W.Z.; Yang, L. Organo-thermal preparation of nanocrystalline cobalt phosphides. Mater. Sci. Eng. B 1997, 49, 135-137. [CrossRef]

33. Yunle, G.; Fan, G.; Yitai, Q.; Huagui, Z.; Ziping, Y. A solvothermal synthesis of ultra-fine iron phosphide. Mater. Res. Bull. 2002, 37, 1101-1105. [CrossRef]

34. Barry, B.M.; Gillan, E.G. Low-Temperature Solvothermal Synthesis of Phosphorus-Rich Transition-Metal Phosphides. Chem. Mater. 2008, 20, 2618-2620. [CrossRef]

35. Ann Aitken, J.; Ganzha-Hazen, V.; Brock, S.L. Solvothermal syntheses of $\mathrm{Cu}_{3} \mathrm{P}$ via reactions of amorphous red phosphorus with a variety of copper sources. J. Solid State Chem. 2005, 178, 970-975. [CrossRef]

36. Xie, Y.; Su, H.L.; Qian, X.F.; Liu, X.M.; Qian, Y.T. A Mild One-Step Solvothermal Route to Metal Phosphides (Metal=Co, Ni, Cu). J. Solid State Chem. 2000, 149, 88-91. [CrossRef]

37. Saadi, F.H.; Carim, A.I.; Verlage, E.; Hemminger, J.C.; Lewis, N.S.; Soriaga, M.P. CoP as an Acid-Stable Active Electrocatalyst for the Hydrogen-Evolution Reaction: Electrochemical Synthesis, Interfacial Characterization and Performance Evaluation. J. Phys. Chem. C 2014, 118, 29294-29300. [CrossRef]

38. Han, S.; Feng, Y.; Zhang, F.; Yang, C.; Yao, Z.; Zhao, W.; Qiu, F.; Yang, L.; Yao, Y.; Zhuang, X.; et al. Metal-Phosphide-Containing Porous Carbons Derived from an Ionic-Polymer Framework and Applied as Highly Efficient Electrochemical Catalysts for Water Splitting. Adv. Funct. Mater. 2015, 25, 3899-3906. [CrossRef]

39. Zou, X.; Zhang, Y. Noble metal-free hydrogen evolution catalysts for water splitting. Chem. Soc. Rev. 2015, 44, 5148-5180. [CrossRef]

40. Muetterties, E.L.; Sauer, J.C. Catalytic properties of metal phosphides. Qualitative assay of catalytic properties. I. J. Am. Chem. Soc. 1974, 96, 3410-3415. [CrossRef]

41. Nozaki, F.; Adachi, R. Chemical composition of the catalyst prepared by reduction of nickel orthophosphate in hydrogen and catalytic activity for partial hydrogenation of 1,3-butadiene. J. Catal. 1975, 40, 166-172. [CrossRef]

42. Nozaki, F.; Kitoh, T.; Sodesawa, T. Promoting effect of oxygen for hydrogenation of butadiene over $\mathrm{Ni}_{2} \mathrm{P}$ catalyst. J. Catal. 1980, 62, 286-293. [CrossRef]

43. Yang, P.; Jiang, Z.; Ying, P.; Li, C. Effect of surface composition on the catalytic performance of molybdenum phosphide catalysts in the hydrogenation of acetonitrile. J. Catal. 2008, 253, 66-73. [CrossRef]

44. Zhang, X.; Zhang, Q.; Guan, J.; He, D.; Hu, H.; Liang, C. Hydrogenation of naphthalene on nickel phosphide supported on silica. Asia-Pac. J. Chem. Eng. 2009, 4, 574-580. [CrossRef]

45. Lee, Y.K.; Oyama, S.T. Bifunctional nature of a $\mathrm{SiO}_{2}$-supported $\mathrm{Ni}_{2} \mathrm{P}$ catalyst for hydrotreating: EXAFS and FTIR studies. J. Catal. 2006, 239, 376-389. [CrossRef]

46. Oyama, S.T.; Lee, Y.K. The active site of nickel phosphide catalysts for the hydrodesulfurization of 4,6-DMDBT. J. Catal. 2008, 258, 393-400. [CrossRef]

47. Wang, X.; Clark, P.; Oyama, S.T. Synthesis, Characterization, and Hydrotreating Activity of Several Iron Group Transition Metal Phosphides. J. Catal. 2002, 208, 321-331. [CrossRef] 
48. Hansen, M.H.; Stern, L.-A.; Feng, L.; Rossmeisl, J.; Hu, X. Widely available active sites on $\mathrm{Ni}_{2} \mathrm{P}$ for electrochemical hydrogen evolution-Insights from first principles calculations. Phys. Chem. Chem. Phys. 2015, 17, 10823-10829. [CrossRef] [PubMed]

49. Fang, Z.; Peng, L.; Qian, Y.; Zhang, X.; Xie, Y.; Cha, J.J.; Yu, G. Dual Tuning of Ni-Co-A (A = P, Se, O) Nanosheets by Anion Substitution and Holey Engineering for Efficient Hydrogen Evolution. J. Am. Chem. Soc. 2018, 140, 5241-5247. [CrossRef] [PubMed]

50. Mishra, I.K.; Zhou, H.; Sun, J.; Qin, F.; Dahal, K.; Bao, J.; Chen, S.; Ren, Z. Hierarchical $\mathrm{CoP} / \mathrm{Ni}_{5} \mathrm{P}_{4} / \mathrm{CoP}$ microsheet arrays as a robust $\mathrm{pH}$-universal electrocatalyst for efficient hydrogen generation. Energy Environ. Sci. 2018, 11, 2246-2252. [CrossRef]

51. Kim, T.-S.; Song, H.J.; Kim, J.-C.; Ju, B.; Kim, D.-W. 3D Architectures of CoxP Using Silk Fibroin Scaffolds: An Active and Stable Electrocatalyst for Hydrogen Generation in Acidic and Alkaline Media. Small 2018, 14, 1801284. [CrossRef] [PubMed]

52. Chang, J.; Feng, L.; Liu, C.; Xing, W. Ni 2 P Makes Application of the PtRu Catalyst Much Stronger in Direct Methanol Fuel Cells. ChemSusChem 2015, 8, 3340-3347. [CrossRef] [PubMed]

53. Chang, J.; Feng, L.; Jiang, K.; Xue, H.; Cai, W.-B.; Liu, C.; Xing, W. Pt-CoP/C as an alternative PtRu/C catalyst for direct methanol fuel cells. J. Mater. Chem. A 2016, 4, 18607-18613. [CrossRef]

54. Zhu, J.; Huang, S.; Key, J.; Nie, S.; Ma, S.; Shen, P.K. Facile synthesis of a molybdenum phosphide (MoP) nanocomposite Pt support for high performance methanol oxidation. Catal. Sci. Technol. 2017, 7, 5974-5981. [CrossRef]

55. Yang, H.; Zhang, Y.; Hu, F.; Wang, Q. Urchin-like CoP Nanocrystals as Hydrogen Evolution Reaction and Oxygen Reduction Reaction Dual-Electrocatalyst with Superior Stability. Nano Lett. 2015, 15, 7616-7620. [CrossRef]

56. Doan-Nguyen, V.V.T.; Zhang, S.; Trigg, E.B.; Agarwal, R.; Li, J.; Su, D.; Winey, K.I.; Murray, C.B. Synthesis and $\mathrm{X}$-ray Characterization of Cobalt Phosphide (Co2P) Nanorods for the Oxygen Reduction Reaction. ACS Nano 2015, 9, 8108-8115. [CrossRef]

57. Zhong, X.; Jiang, Y.; Chen, X.; Wang, L.; Zhuang, G.; Li, X.; Wang, J.-G. Integrating cobalt phosphide and cobalt nitride-embedded nitrogen-rich nanocarbons: High-performance bifunctional electrocatalysts for oxygen reduction and evolution. J. Mater. Chem. A 2016, 4, 10575-10584. [CrossRef]

58. Dong, Y.; Kong, L.; Jiang, P.; Wang, G.; Zhao, N.; Zhang, H.; Tang, B. A General Strategy To Fabricate NixP as Highly Efficient Cocatalyst via Photoreduction Deposition for Hydrogen Evolution. ACS Sustain. Chem. Eng. 2017, 5, 6845-6853. [CrossRef]

59. Shen, R.; Xie, J.; Lu, X.; Chen, $X . ;$ Li, X. Bifunctional $\mathrm{Cu}_{3} P$ Decorated $g-\mathrm{C}_{3} \mathrm{~N}_{4}$ Nanosheets as a Highly Active and Robust Visible-Light Photocatalyst for $\mathrm{H}_{2}$ Production. ACS Sustain. Chem. Eng. 2018, 6, 4026-4036. [CrossRef]

60. Wang, P.; Zhan, S.; Wang, H.; Xia, Y.; Hou, Q.; Zhou, Q.; Li, Y.; Kumar, R.R. Cobalt phosphide nanowires as efficient co-catalyst for photocatalytic hydrogen evolution over Zn0.5Cd0.5S. Appl. Catal. B Environ. 2018, 230, 210-219. [CrossRef]

61. Zhao, H.; Wang, J.; Dong, Y.; Jiang, P. Noble-Metal-Free Iron Phosphide Cocatalyst Loaded Graphitic Carbon Nitride as an Efficient and Robust Photocatalyst for Hydrogen Evolution under Visible Light Irradiation. ACS Sustain. Chem. Eng. 2017, 5, 8053-8060. [CrossRef]

62. Bi, L.; Gao, X.; Zhang, L.; Wang, D.; Zou, X.; Xie, T. Enhanced Photocatalytic Hydrogen Evolution of $\mathrm{NiCoP} / \mathrm{g}-\mathrm{C}_{3} \mathrm{~N}_{4}$ with Improved Separation Efficiency and Charge Transfer Efficiency. ChemSusChem 2018, 11, 276-284. [CrossRef]

63. Gunstone, F.D.; Harwood, J.L.; Dijkstra, A.J. The Lipid Handbook; CRC Press: Boca Raton, FL, USA, 2007.

64. Hu, Q.; Sommerfeld, M.; Jarvis, E.; Ghirardi, M.; Posewitz, M.; Seibert, M.; Darzins, A. Microalgal triacylglycerols as feedstocks for biofuel production: Perspectives and advances. Plant J. 2008, 54, 621-639. [CrossRef] [PubMed]

65. Austin, A. Boeing planes successfully fly with biofuels. Biodiesel Magazine, 15 January 2009.

66. Sotelo-Boyás, R.; Trejo-Zárragaand, F.; de Jesús Hernández-Loyo, F. Hydroconversion of Triglycerides into Green Liquid Fuels (Chapter 8) in Hydrogenation (Iyad Karamé ed.); IntechOpen: London, UK, 2012.

67. Zeman, N. Neste Oil starts construction on Europe's largest renewable fuels plant. Biodiesel Magazine, 27 May 2009. 
68. Izadifar, M.; Jahromi, M.Z. Application of genetic algorithm for optimization of vegetable oil hydrogenation process. J. Food Eng. 2007, 78, 1-8. [CrossRef]

69. US Department of Energy. Energy Efficiency and Renewable Energy. Available online: https://afdc.energy. gov / fuels/biodiesel_production.html (accessed on 28 February 2019).

70. Alvarez-Galvan, M.C.; Blanco-Brieva, G.; Capel-Sanchez, M.; Morales-delaRosa, S.; Campos-Martin, J.M.; Fierro, J.L.G. Metal phosphide catalysts for the hydrotreatment of non-edible vegetable oils. Catal. Today 2018, 302, 242-249. [CrossRef]

71. Satyarthi, J.K.; Chiranjeevi, T.; Gokak, D.T.; Viswanathan, P.S. An overview of catalytic conversion of vegetable oils/fats into middle distillates. Catal. Sci. Technol. 2013, 3, 70-80. [CrossRef]

72. Ali, M.F.; el Ali, B.M.; Speight, J.G. Handbook of Industrial Chemistry: Organic Chemicals; Mc Graw-Hill: New York, NY, USA, 2005.

73. Ancheyta, J.; Trejo, F.; Rana, M.S. Asphaltenes: Chemical Transformation during Hydroprocessing of Heavy Oils; CRC Press: Boca Raton, FL, USA, 2009.

74. Sotelo-Boyas, R.; Liu, Y.Y.; Minowa, T. Renewable Diesel Production from the Hydrotreating of Rapeseed Oil with $\mathrm{Pt} / \mathrm{Zeolite}$ and $\mathrm{NiMo} / \mathrm{Al}_{2} \mathrm{O}_{3}$ Catalysts. Ind. Eng. Chem. Res. 2011, 50, 2791-2799. [CrossRef]

75. Li, K.; Wang, R.; Chen, J. Hydrodeoxygenation of Anisole over Silica-Supported $\mathrm{Ni}_{2} \mathrm{P}, \mathrm{MoP}$, and NiMoP Catalysts. Energy Fuels 2011, 25, 854-863. [CrossRef]

76. Duan, X.P.; Teng, Y.; Wang, A.J.; Kogan, V.M.; Li, X.; Wang, Y. Role of sulfur in hydrotreating catalysis over nickel phosphide. J. Catal. 2009, 261, 232-240. [CrossRef]

77. He, Z.; Wang, X. Hydrodeoxygenation of model compounds and catalytic systems for pyrolysis bio-oils upgrading. Catal. Sustain. Chem. 2012, 28-52. [CrossRef]

78. Bowker, R.H.; Smith, M.C.; Pease, M.L.; Slenkamp, K.M.; Kovarik, L.; Bussell, M.E. Synthesis and Hydrodeoxygenation Properties of Ruthenium Phosphide Catalysts. ACS Catal. 2011, 1, 917-922. [CrossRef]

79. Hicks, J.C. Advances in C-O Bond Transformations in Lignin-Derived Compounds for Biofuels Production. J. Phys. Chem. Lett. 2011, 2, 2280-2287. [CrossRef]

80. Talukdar, A.K.; Bhattacharyya, K.G.; Sivasanker, S. Hydrogenation of phenol over supported platinum and palladium catalysts. Appl. Catal. A-Gen. 1993, 96, 229-239. [CrossRef]

81. Zhao, H.Y.; Li, D.; Bui, P.; Oyama, S.T. Hydrodeoxygenation of guaiacol as model compound for pyrolysis oil on transition metal phosphide hydroprocessing catalysts. Appl. Catal. A Gen. 2011, 391, 305-310. [CrossRef]

82. Chen, J.; Shi, H.; Li, L.; Li, K. Deoxygenation of methyl laurate as a model compound to hydrocarbons on transition metal phosphide catalysts. Appl. Catal. B Environ. 2014, 144, 870-884. [CrossRef]

83. Yang, Y.; Ochoa-Hernández, C.; Pizarro, P.; de la Peña O'Shea, V.A.; Coronado, J.M.; Serrano, D.P. Influence of the $\mathrm{Ni} / \mathrm{P}$ ratio and metal loading on the performance of NixPy/SBA-15 catalysts for the hydrodeoxygenation of methyl oleate. Fuel 2015, 144, 60-70. [CrossRef]

84. Stinner, C.; Tang, Z.; Haouas, M.; Weber, T.; Prins, R. Preparation and P-31 NMR characterization of nickel phosphides on silica. J. Catal. 2002, 208, 456-466. [CrossRef]

85. Shi, H.; Chen, J.X.; Yang, Y.; Tian, S.S. Catalytic deoxygenation of methyl laurate as a model compound to hydrocarbons on nickel phosphide catalysts: Remarkable support effect. Fuel Process. Technol. 2014, 118, 161-170. [CrossRef]

86. Yang, Y.; Chen, J.X.; Shi, H. Deoxygenation of Methyl Laurate as a Model Compound to Hydrocarbons on $\mathrm{Ni}_{2} \mathrm{P} / \mathrm{SiO}_{2}, \mathrm{Ni2P} / \mathrm{MCM}-41$, and Ni2P/SBA-15 Catalysts with Different Dispersions. Energy Fuels 2013, 27, 3400-3409. [CrossRef]

87. Deliy, I.; Shamanaev, I.; Gerasimov, E.; Pakharukova, V.; Yakovlev, I.; Lapina, O.; Aleksandrov, P.; Bukhtiyarova, G. HDO of Methyl Palmitate over Silica-Supported Ni Phosphides: Insight into Ni/P Effect. Catalysts 2017, 7, 298. [CrossRef]

88. Ruinart de Brimont, M.; Dupont, C.; Daudin, A.; Geantet, C.; Raybaud, P. Deoxygenation mechanisms on Ni-promoted $\mathrm{MoS}_{2}$ bulk catalysts: A combined experimental and theoretical study. J. Catal. 2012, 286, 153-164. [CrossRef]

89. Guan, Q.; Wan, F.; Han, F.; Liu, Z.; Li, W. Hydrodeoxygenation of methyl palmitate over MCM-41 supported nickel phosphide catalysts. Catal. Today 2016, 259, 467-473. [CrossRef]

90. Shamanaev, I.V.; Deliy, I.V.; Aleksandrov, P.V.; Gerasimov, E.Y.; Pakharukova, V.P.; Kodenev, E.G.; Ayupov, A.B.; Andreev, A.S.; Lapina, O.B.; Bukhtiyarova, G.A. Effect of precursor on the catalytic properties of $\mathrm{Ni}_{2} \mathrm{P} / \mathrm{SiO}_{2}$ in methyl palmitate hydrodeoxygenation. RSC Adv. 2016, 6, 30372-30383. [CrossRef] 
91. Cheng, S.; Wei, L.; Zhao, X.; Julson, J. Application, Deactivation, and Regeneration of Heterogeneous Catalysts in Bio-Oil Upgrading. Catalysts 2016, 6, 195. [CrossRef]

92. Twaiq, F.A.; Zabidi, N.A.M.; Bhatia, S. Catalytic Conversion of Palm Oil to Hydrocarbons: Performance of Various Zeolite Catalysts. Ind. Eng. Chem. Res. 1999, 38, 3230-3237. [CrossRef]

93. Zhang, G.; Zhang, X.; Bai, T.; Chen, T.; Fan, W. Coking kinetics and influence of reaction-regeneration on acidity, activity and deactivation of Zn/HZSM-5 catalyst during methanol aromatization. J. Energy Chem. 2015, 24, 108-118. [CrossRef]

94. Liu, P.; Rodriguez, J.A.; Takahashi, Y.; Nakamura, K. Water-gas-shift reaction on a Ni2P(001) catalyst: Formation of oxy-phosphides and highly active reaction sites. J. Catal. 2009, 262, 294-303. [CrossRef]

95. Zhu, X.; Lobban, L.L.; Mallinson, R.G.; Resasco, D.E. Bifunctional transalkylation and hydrodeoxygenation of anisole over a Pt/HBeta catalyst. J. Catal. 2011, 281, 21-29. [CrossRef]

96. Song, W.; Liu, Y.; Baráth, E.; Zhao, C.; Lercher, J.A. Synergistic effects of Ni and acid sites for hydrogenation and $\mathrm{C}-\mathrm{O}$ bond cleavage of substituted phenols. Green Chem. 2015, 17, 1204-1218. [CrossRef]

97. Taufiqurrahmi, N.; Mohamed, A.R.; Bhatia, S. Nanocrystalline zeolite beta and zeolite Y as catalysts in used palm oil cracking for the production of biofuel. J. Nanopart. Res. 2011, 13, 3177-3189. [CrossRef]

98. Josl, R.; Klingmann, R.; Traa, Y.; Gläser, R.; Weitkamp, J. Regeneration of zeolite catalysts deactivated in isobutane/butene alkylation: An in situ FTIR investigation at elevated $\mathrm{H}_{2}$ pressure. Catal. Commun. 2004, 5 , 239-241. [CrossRef]

99. Ivanov, D.P.; Sobolev, V.I.; Panov, G.I. Deactivation by coking and regeneration of zeolite catalysts for benzene-to-phenol oxidation. Appl. Catal. A Gen. 2003, 241, 113-121. [CrossRef]

100. Si, Z.; Zhang, X.; Wang, C.; Ma, L.; Dong, R. An Overview on Catalytic Hydrodeoxygenation of Pyrolysis Oil and Its Model Compounds. Catalysts 2017, 7, 169. [CrossRef]

101. Yu, Z.Q.; Wang, A.J.; Liu, S.; Yao, Y.L.; Sun, Z.C.; Li, X.; Liu, Y.Y.; Wang, Y.; Camaioni, D.M.; Lercher, J.A. Hydrodeoxygenation of phenolic compounds to cycloalkanes over supported nickel phosphides. Catal. Today 2019, 319, 48-56. [CrossRef]

102. Guo, T.; Chen, J.X.; Li, K.L. Promotion Effect of Steam Treatment on Activity of $\mathrm{Ni}_{2} \mathrm{P} / \mathrm{SiO}_{2}$ for Hydrodechlorination of Chlorobenzene. Chin. J. Catal. 2012, 33, 1080-1085. [CrossRef]

103. Li, D.; Bui, P.; Zhao, H.Y.; Oyama, S.T.; Dou, T.; Shen, Z.H. Rake mechanism for the deoxygenation of ethanol over a supported $\mathrm{Ni}_{2} \mathrm{P} / \mathrm{SiO}_{2}$ catalyst. J. Catal. 2012, 290, 1-12. [CrossRef]

104. Iino, A.; Cho, A.; Takagaki, A.; Kikuchi, R.; Oyama, S.T. Kinetic studies of hydrodeoxygenation of 2-methyltetrahydrofuran on a $\mathrm{Ni}_{2} \mathrm{P} / \mathrm{SiO}_{2}$ catalyst at medium pressure. J. Catal. 2014, 311, 17-27. [CrossRef]

105. Shafaghat, H.; Rezaei, P.S.; Daud, W. Effective parameters on selective catalytic hydrodeoxygenation of phenolic compounds of pyrolysis bio-oil to high-value hydrocarbons. RSC Adv. 2015, 5, 103999-104042. [CrossRef]

106. Robinson, A.M.; Hensley, J.E.; Medlin, J.W. Bifunctional Catalysts for Upgrading of Biomass-Derived Oxygenates: A Review. ACS Catal. 2016, 6, 5026-5043. [CrossRef]

107. Peroni, M.; Lee, I.; Huang, X.; Barath, E.; Gutierrez, O.Y.; Lercher, J.A. Deoxygenation of Palmitic Acid on Unsupported Transition-Metal Phosphides. ACS Catal. 2017, 7, 6331-6341. [CrossRef]

108. Li, X.; Luo, X.Y.; Jin, Y.B.; Li, J.Y.; Zhang, H.D.; Zhang, A.P.; Xie, J. Heterogeneous sulfur-free hydrodeoxygenation catalysts for selectively upgrading the renewable bio-oils to second generation biofuels. Renew. Sustain. Energy Rev. 2018, 82, 3762-3797. [CrossRef]

109. Jain, V.; Bonita, Y.; Brown, A.; Taconi, A.; Hicks, J.C.; Rai, N. Mechanistic insights into hydrodeoxygenation of phenol on bimetallic phosphide catalysts. Catal. Sci. Technol. 2018, 8, 4083-4096. [CrossRef]

110. Cecilia, J.A.; Infantes-Molina, A.; Rodríguez-Castellón, E.; Jiménez-López, A.; Oyama, S.T. Oxygen-removal of dibenzofuran as a model compound in biomass derived bio-oil on nickel phosphide catalysts: Role of phosphorus. Appl. Catal. B Environ. 2013, 136-137, 140-149. [CrossRef]

111. Zhang, Z.N.; Tang, M.X.; Chen, J.X. Effects of $\mathrm{P} / \mathrm{Ni}$ ratio and $\mathrm{Ni}$ content on performance of gamma- $\mathrm{Al}_{2} \mathrm{O}_{3}$-supported nickel phosphides for deoxygenation of methyl laurate to hydrocarbons. Appl. Surf. Sci. 2016, 360, 353-364. [CrossRef]

112. Liu, Y.H.; Yao, L.; Xin, H.; Wang, G.S.; Li, D.; Hu, C.W. The production of diesel-like hydrocarbons from palmitic acid over HZSM-22 supported nickel phosphide catalysts. Appl. Catal. B-Environ. 2015, 174, 504-514. [CrossRef] 
113. Goncalves, V.O.O.; de Souza, P.M.; Cabioc'h, T.; da Silva, V.T.; Noronha, F.B.; Richard, F. Effect of P/Ni ratio on the performance of nickel phosphide phases supported on zirconia for the hydrodeoxygenation of m-cresol. Catal. Commun. 2019, 119, 33-38. [CrossRef]

114. Koranyi, T.I.; Vit, Z.; Poduval, D.G.; Ryoo, R.; Kim, H.S.; Hensen, E.J.M. SBA-15-supported nickel phosphide hydrotreating catalysts. J. Catal. 2008, 253, 119-131. [CrossRef]

115. Xin, H.; Guo, K.; Li, D.; Yang, H.Q.; Hu, C.W. Production of high-grade diesel from palmitic acid over activated carbon-supported nickel phosphide catalysts. Appl. Catal. B-Environ. 2016, 187, 375-385. [CrossRef]

116. Wu, S.K.; Lai, P.C.; Lin, Y.C. Atmospheric Hydrodeoxygenation of Guaiacol over Nickel Phosphide Catalysts: Effect of Phosphorus Composition. Catal. Lett. 2014, 144, 878-889. [CrossRef]

117. Guo, C.; Rao, K.T.V.; Yuan, Z.S.; He, S.; Rohani, S.; Xu, C.B. Hydrodeoxygenation of fast pyrolysis oil with novel activated carbon-supported NiP and CoP catalysts. Chem. Eng. Sci. 2018, 178, 248-259. [CrossRef]

118. Pham, L.K.H.; Tran, T.T.V.; Kongparakul, S.; Reubroycharoen, P.; Kamjanakom, S.; Guan, G.Q.; Samart, C. Formation and activity of activated carbon supported $\mathrm{Ni}_{2} \mathrm{P}$ catalysts for atmospheric deoxygenation of waste cooking oil. Fuel Process. Technol. 2019, 185, 117-125. [CrossRef]

119. Dierks, M.; Cao, Z.W.; Manayil, J.C.; Akilavasan, J.; Wilson, K.; Schuth, F.; Rinaldi, R. Impact of Hydrophobic Organohybrid Silicas on the Stability of $\mathrm{Ni}_{2} \mathrm{P}$ Catalyst Phase in the Hydrodeoxygenation of Biophenols. ChemCatChem 2018, 10, 2219-2231. [CrossRef]

120. Ochoa-Hernández, C.; Yang, Y.; Pizarro, P.; de la Peña O’Shea, V.A.; Coronado, J.M.; Serrano, D.P. Hydrocarbons production through hydrotreating of methyl esters over Ni and Co supported on SBA-15 and Al-SBA-15. Catal. Today 2013, 210, 81-88. [CrossRef]

121. Deliy, I.V.; Shamanaev, I.V.; Aleksandrov, P.V.; Gerasimov, E.Y.; Pakharukova, V.P.; Kodenev, E.G.; Yakovlev, I.V.; Lapina, O.B.; Bukhtiyarova, G.A. Support Effect on the Performance of $\mathrm{Ni}_{2} \mathrm{P}$ Catalysts in the Hydrodeoxygenation of Methyl Palmitate. Catalysts 2018, 8, 515. [CrossRef]

122. Yang, Y.; Ochoa-Hernández, C.; de la Peña O'Shea, V.A.; Coronado, J.M.; Serrano, D.P. Ni2P/SBA-15 As a Hydrodeoxygenation Catalyst with Enhanced Selectivity for the Conversion of Methyl Oleate Inton-Octadecane. ACS Catal. 2012, 2, 592-598. [CrossRef]

123. Zhu, T.H.; Song, H.; Dai, X.Y.; Song, H.L. Preparation of Ni2P/Al-SBA-15 catalyst and its performance for benzofuran hydrodeoxygenation. Chin. J. Chem. Eng. 2017, 25, 1784-1790. [CrossRef]

124. Berenguer, A.; Bennett, J.A.; Hunns, J.; Moreno, I.; Coronado, J.M.; Lee, A.F.; Pizarro, P.; Wilson, K.; Serrano, D.P. Catalytic hydrodeoxygenation of $\mathrm{m}$-cresol over Ni2P/hierarchical ZSM-5. Catal. Today 2018, 304, 72-79. [CrossRef]

125. Cecilia, J.A.; Infantes-Molina, A.; Sanmartin-Donoso, J.; Rodriguez-Aguado, E.; Ballesteros-Plata, D.; Rodriguez-Castellon, E. Enhanced $\mathrm{HDO}$ activity of $\mathrm{Ni}_{2} \mathrm{P}$ promoted with noble metals. Catal. Sci. Technol. 2016, 6, 7323-7333. [CrossRef]

126. Liu, X.G.; Li, Z.Y.; Zhang, B.Q.; Hu, M.C. Improvement of hydrodeoxygenation stability of nickel phosphide based catalysts by silica modification as structural promoter. Fuel 2017, 204, 144-151. [CrossRef]

127. Cheng, R.H.; Shu, Y.Y.; Li, L.; Zheng, M.Y.; Wang, X.D.; Wang, A.Q.; Zhang, T. Synthesis and characterization of high surface area molybdenum phosphide. Appl. Catal. A-Gen. 2007, 316, 160-168. [CrossRef]

128. Whiffen, V.M.L.; Smith, K.J.; Straus, S.K. The influence of citric acid on the synthesis and activity of high surface area MoP for the hydrodeoxygenation of 4-methylphenol. Appl. Catal. A-Gen. 2012, 419, 111-125. [CrossRef]

129. Yang, Y.X.; Ochoa-Hernandez, C.; O'Shea, V.A.D.; Pizarro, P.; Coronado, J.M.; Serrano, D.P. Transition Metal Phosphide Nanoparticles Supported on SBA-15 as Highly Selective Hydrodeoxygenation Catalysts for the Production of Advanced Biofuels. J. Nanosci. Nanotechnol. 2015, 15, 6642-6650. [CrossRef]

130. Shamanaev, I.V.; Deliy, I.V.; Gerasimov, E.Y.; Pakharukova, V.P.; Kodenev, E.G.; Aleksandrov, P.V.; Bukhtiyarova, G.A. Synergetic Effect of $\mathrm{Ni}_{2} \mathrm{P} / \mathrm{SiO}_{2}$ and gamma- $\mathrm{Al}_{2} \mathrm{O}_{3}$ Physical Mixture in Hydrodeoxygenation of Methyl Palmitate. Catalysts 2017, 7, 329. [CrossRef]

131. Shamanaev, I.V.; Deliy, I.V.; Pakharukova, V.P.; Gerasimov, E.Y.; Rogov, V.A.; Bukhtiyarova, G.A. Effect of the preparation conditions on the physicochemical and catalytic properties of $\mathrm{Ni}_{2} \mathrm{P} / \mathrm{SiO}_{2}$ catalysts. Russ. Chem. Bull. 2015, 64, 2361-2370. [CrossRef]

132. Peroni, M.; Mancino, G.; Baráth, E.; Gutiérrez, O.Y.; Lercher, J.A. Bulk and $\gamma-\mathrm{Al}_{2} \mathrm{O}_{3}$-supported $\mathrm{Ni}_{2} \mathrm{P}$ and MoP for hydrodeoxygenation of palmitic acid. Appl. Catal. B Environ. 2016, 180, 301-311. [CrossRef] 
133. Liu, S.Y.; Zhu, Q.Q.; Guan, Q.X.; He, L.N.; Li, W. Bio-aviation fuel production from hydroprocessing castor oil promoted by the nickel-based bifunctional catalysts. Bioresour. Technol. 2015, 183, 93-100. [CrossRef] [PubMed]

134. Phimsen, S.; Kiatkittipong, W.; Yamada, H.; Tagawa, T.; Kiatkittipong, K.; Laosiripojana, N.; Assabumrungrat, S. Oil extracted from spent coffee grounds for bio-hydrotreated diesel production. Energy Convers. Manag. 2016, 126, 1028-1036. [CrossRef]

135. Zarchin, R.; Rabaev, M.; Vidruk-Nehemya, R.; Landau, M.V.; Herskowitz, M. Hydroprocessing of soybean oil on nickel-phosphide supported catalysts. Fuel 2015, 139, 684-691. [CrossRef] 